\title{
Contamination assessment of arsenic and heavy metals in a typical abandoned estuary wetland-a case study of the Yellow River Delta Natural Reserve
}

\author{
Zhenglei Xie • Zhigao Sun • Hua Zhang • Jun Zhai
}

Received: 16 January 2014 / Accepted: 30 June 2014 / Published online: 18 July 2014

(C) Springer International Publishing Switzerland 2014

\begin{abstract}
Coastal and estuarine areas are often polluted by heavy metals that result from industrial production and agricultural activities. In this study, we investigated the concentration trait and vertical pattern of trace elements, such as $\mathrm{As}, \mathrm{Cd}, \mathrm{Ni}, \mathrm{Zn}, \mathrm{Pb}, \mathrm{Cu}$, and $\mathrm{Cr}$, and the relationship between those trace elements and the soil properties in coastal wetlands using 28 profiles that were surveyed across the Diaokouhe Nature Reserve (DKHNR). The goal
\end{abstract}

\section{Z. Xie}

School of Geography \& Environment, Jiangxi Normal University,

No. 99, Ziyang Road, Nanchang 330022,

People's Republic of China

e-mail: xz12121@163.com

\section{Z. Sun}

Yantai Institute of Coastal Zone Research, Chinese Academy of Sciences,

No. 17, Chunhui Road, Yantai 264003,

People's Republic of China

e-mail: zgsun@yic.ac.cn

\section{H. Zhang}

Key Laboratory of Education Ministry for Poyang Lake Wetland \& Watershed Research, Jiangxi Normal University, No. 99, Ziyang Road, Nanchang 330022,

People's Republic of China

e-mail: 249220339@qq.com

J. Zhai $(\bowtie)$

Satellite Environment Center,

Ministry of Environmental Protection,

No. 4, Fengde East Road, Yongfeng Industrial Base,

Zhongguancun, Haidian, Beijing 100094,

People's Republic of China

e-mail: zhaij@1reis.ac.cn of this study is to investigate profile distribution characteristics of heavy metals in different wetland types and their variations with the soil depth to assess heavy metal pollution using pollution indices and to identify the pollution sources using multivariate analysis and sediment quality guidelines. Principal component analysis, cluster analysis, and pollution level indices were applied to evaluate the contamination conditions due to wetland degradation. The findings indicated that the concentration of trace elements decreased with the soil depth, while Cd increases with soil depth. The As concentrations in reed swamps and Suaeda heteroptera surface layers were slightly higher than those in other land use types. All six heavy metals, i.e., $\mathrm{Ni}, \mathrm{Cu}$, $\mathrm{As}, \mathrm{Zn}, \mathrm{Cr}$, and $\mathrm{Pb}$, were strongly associated with $\mathrm{PC} 1$ (positive loading) and could reflect the contribution of natural geological sources of metals into the coastal sediments. PC2 is highly associated with $\mathrm{Cd}$ and could represent anthropogenic sources of metal pollution. Most of the heavy metals exhibited significant positive correlations with total concentrations; however, no significant correlations were observed between them and the soil salt and soil organic carbon. Soil organic carbon exhibited a positive linear relationship with $\mathrm{Cu}, \mathrm{Pb}$, and $\mathrm{Zn}$ in the first soil layer $(0-20 \mathrm{~cm})$; $\mathrm{As}, \mathrm{Cr}, \mathrm{Cu}, \mathrm{Ni}, \mathrm{Pb}$, and $\mathrm{Zn}$ in the second layer $(20-40 \mathrm{~cm})$; and $\mathrm{As}, \mathrm{Cr}, \mathrm{Cu}, \mathrm{Ni}, \mathrm{Pb}$, and $\mathrm{Zn}$ in the third layer $(40-60 \mathrm{~cm})$. Soil organic carbon exhibited only a negative correlation with $\mathrm{Cd}(P<0.05)$, in the second and third layers. $\mathrm{As}, \mathrm{Cr}, \mathrm{Cu}, \mathrm{Ni}, \mathrm{Pb}$, and $\mathrm{Zn}$ exhibited lower geoaccumulation index values ( $I_{\text {geo }}$ values), which averaged less than 0 in the three soil layers, this finding indicates that the soils have remained unpolluted by these heavy metals. The mean concentrations of these trace 
elements were lower than Class I criteria. The degradation wetland restoration suggestions have also been provided in such a way as to restore the reserved flow path of the Yellow River. The results that are associated with trace element contamination would be helpful in providing scientific directions to restore wetlands across the world.

Keywords Trace element - Vertical distribution . Contamination assessment. Wetland restoration . Abandoned estuary

\section{Introduction}

Coastal ecosystems are currently affected by natural environmental changes, anthropogenic activities, and synergistic combinations of the two. The large and growing extent of human activities in coastal areas has caused or enhanced a variety of environmental problems (Canuto et al. 2013; Cui et al. 2013; Liu et al. 2014). Coastal wetlands are remarkable and are crucial ecosystems in terms of environmental health, ecosystem services function, distinctive geomorphologic features, typical vegetation and faunal associations, and human activities that are related to their singular environment (Li et al. 2007). Estuarine and coastal areas are complex and important ecosystems in which many critical ecological processes occur. Simultaneously, these areas also provide habitats for a substantial amount of flora and fauna and often face increasing populations and anthropogenic activities (Bai et al. 2012; Canuto et al. 2013; Rodrigues et al. 2013). However, they are often the ultimate receptacles of various anthropogenic pollutants that arise from industrial processes, urbanization, agricultural activities, and domestic waste (Ip et al. 2007; Bastami et al. 2012; Gan et al. 2013). Wetlands have long been recognized as an important sink for heavy metals due to having a variety of physical, chemical, and biological processes that involve sedimentation, setting, adsorption, precipitation, and adsorption, and induced changes in biogeochemical cycles by plants and bacteria (Chandra et al. 2013; Jiao et al. 2014; Xin et al. 2014). Since the 1980s, rapid industrialization and economic development in China has caused serious environmental pollution, which has been particularly substantial in estuarine and coastal areas, which are subjected to multiple environmental pressures (Barba-Brioso et al. 2010; Magesh et al. 2013; Wang et al. 2013).
Heavy metals are the most serious pollutants and can cause many detrimental diseases that result from their high toxicity, persistence, and bio-accumulation (Zhang et al. 2009a; Hu et al. 2013a; Zamani-Ahmadmahmoodi et al. 2013). Heavy metal pollutants have been considered to be one of the most critical global pollutants and pose a serious threat to human health and natural ecosystems (Lotze et al. 2006; Li et al. 2007; Li et al. 2009; Fang et al. 2009; Arik and Yaldiz 2010; Deng et al. 2010; Naser 2013; Zhang et al. 2009b). The first national soil pollution status survey bulletin released on April 17, 2014 launched by the Ministry of Environmental Protection and Ministry of Land and Resources of the People's Republic of China demonstrated that the ratio of exceeding soil standards in all of the samples is $16.1 \%$ and the rate of arable land reaches $19.4 \%$, while the ratio of $\mathrm{Cd}$ is $7.0 \%$ in all of the samples. At the same time, the Blue Book of Land Consolidation issued by China Land Consolidation and Rehabilitation in May 24, 2014 demonstrated that the areas of arable land in China that have been contaminated by heavy metal reach $33,333 \mathrm{~km}^{2}$, especially in the surrounding areas of large cities, major truck lines, and river banks. At the same time, this soil survey also found that the overstandard ratio in oil-producing regions in the 494 samples is $23.6 \%{ }^{1}$ Heavy metal contamination in estuarine and coastal areas has expanded in China because of the potential ecological effects and because of public concern for seafood safety in association with these metals (Feng et al. 2011; Pan and Wang 2012; Yang et al. 2012; Hu et al. 2013b). Many previous studies have reported that heavy metal contamination has occurred in river basins or estuaries due to the cause-effect relationship between human effects and the soil quality (Xiao et al. 2011; Karim et al. 2013). Therefore, it is necessary to investigate distributions and the extent of heavy metal pollution in coastal wetlands and to provide scientific suggestions for coastal management (Chatterjee et al. 2009; Liu et al. 2014).

The ecological risk that is posed by heavy metals has been assessed based on different quality standards (Liu et al. 2010; Bai et al. 2011c; Nazeer et al. 2014). Its objective is to assess the possibility and degree that the chemicals (in a specified amount) and physical factors affect humans, animals, and plants or ecosystems (Zhang et al. 2014). Several indices have been developed to assess trace element contamination levels, such as the enrichment factor (EF), contamination factor (CF) (Raj and

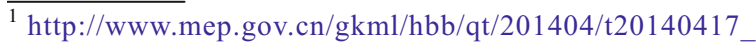
270670.htm
} 
Jayaprakash 2008), metal pollution index (MPI), and geo-accumulation index $\left(I_{\text {geo }}\right)$ (Cui et al. 2009; Lin et al. 2011). The primary research included the application of the EF and multivariate statistical analysis, assessing heavy metal contamination (Zhang et al. 2009a, b), the geoaccumulation index $\left(I_{\mathrm{geo}}\right)$, and the MPI (Müller 1981; Lin et al. 2011; Li et al. 2013). Bai et al. (2011a) analyzed $\mathrm{As}, \mathrm{Cd}, \mathrm{Cu}, \mathrm{Ni}, \mathrm{Pb}$, and $\mathrm{Zn}$ concentrations and assessed their contamination changes in roadside soils in both longterm abandoned tillage (LAT) and short-term abandoned tillage (SAT) belts. Bai et al. (2011b) described heavy mental concentrations in the Yellow River Delta (YRD) using the contamination index method. Vertical heavy metal patterns can contribute as an input or as an independent validation for a biogeochemical model and, thus, provide valuable information for examining the response of terrestrial ecosystems to global changes. Previous studies have primarily focused on the heavy metals in deeper soils and the relevant driving factors. However, the vertical distributions of heavy metals in coastal wetlands remain poorly understood (Yang et al. 2010). Therefore, improved knowledge of heavy metal distributions and determinants for different soil depths are essential for determining whether heavy metals in deep soil layers will accelerate. Due to changes in the water sediments, marine dynamics, and human activities that are caused by ceased river flows, the topography of the Diaokouhe course in the abandoned Yellow River Delta Natural Reserve (YRDNR) determines the reserved flow path and the natural features and ecosystems have changed substantially (Rodrigues et al. 2013). The study area has witnessed rapid industrial growth and petrochemical industry development, and the Shengli Oilfield located in the DKHNR is considered to be the second largest oil reserve in China. Coastal and marine environments that receive intensive industrial effluents are recognized as hotspots for high heavy metal concentrations (Sale et al. 2010; Naser 2013). The wetland restoration project that was initiated in 2010 has greatly influenced wetland landscape patterns in the lower reaches of the Yellow River (Huang et al. 2012). Variations in the average water discharge (SD) and sediment load (SL) at the Lijin hydrological station were observed in the YRD due to the wetland restorations (Table 1), which is considered to be a major limiting factor for soil heavy metal mobilization and transformation in wetland ecosystems. Because of the channel in the lower reaches, monthly water discharge and sediment loads have greatly increased since regulation was enacted, especially from June to July. Much attention has been given to comparing trace element concentrations

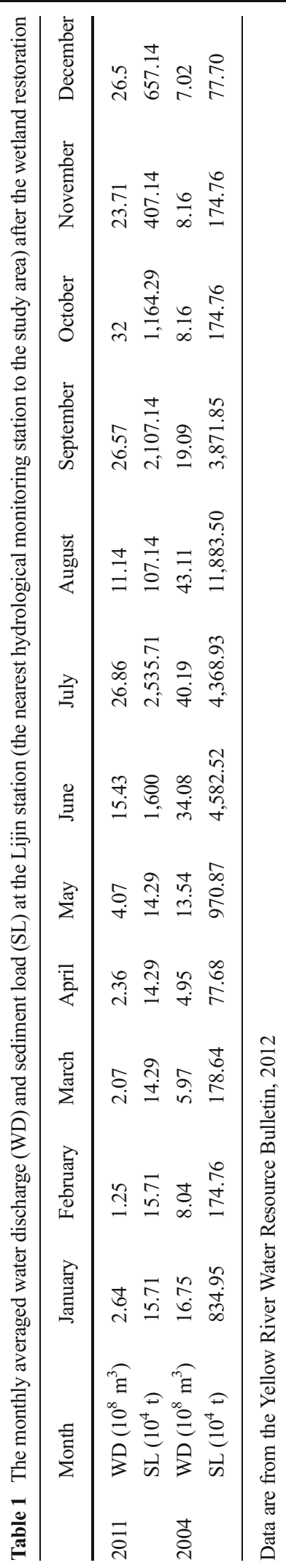


both before and after an ecological event (Ye et al. 2011; Ranjan et al. 2013). Huang et al. (2012) applied HJ-1 microsatellite remote sensing data to monitor and evaluate the effect of wetland restoration through water transfer projects in the YRD. However, little is known about the vertical distributions of heavy metal concentrations in coastal wetlands after the wetland restoration project in 2010 . Therefore, research is urgently needed to determine the heavy metal concentrations since the wetland restoration project was enacted and to improve our understanding of biogeochemical cycles in coastal areas and their potential feedback to global environmental changes (Nobi et al. 2010).

Understanding heavy metal distributions and accumulations plays a crucial role in ecological risk assessment and facilitates the restoration of wetlands. In this study, we investigated the vertical distributions of heavy metals using 28 profiles that were obtained from a regional soil survey that was conducted on coastal wetlands during 2010. In this study, the CF, $I_{\text {geo }}$, and pollution load index (PLI) were applied to evaluate heavy metal pollution and determine heavy metal sources. Specifically, this study aimed (1) to investigate profile distribution characteristics of arsenic and heavy metals in different wetland types and their variations with soil depth, (2) to assess heavy metal pollution using pollution indices and to identify the pollution sources using multivariate analysis and sediment quality guidelines, and (3) to provide protection management measures for the abandoned wetlands in the abandoned YRDNR.

\section{Materials and methods}

Study area and wetland restoration project

In 1992, the YRDNR was established for protecting endangered bird species and its habitats at the YR Mouth of the newly formed wetland ecosystem. The Diaokouhe Nature Reserve (DKHNR) is located in the north part of the YRD and is the old course of the YR (Fig. 1). The tail reaches of the DKHNR contain the reserved flow path of the YR and part of the YRDNR. The river has a length of $55 \mathrm{~km}$ and once flowed to the ocean in the north before the YR diversion in May 1976; every shift in the YR has produced abandoned river courses. The YR was artificially shifted again in May 1976 at Yuwa from the Diaokouhe course to the Qingshuigou course. In 1992, the State Planning Commission approved the Plan Report of Flow Path to Ocean of the YR, which was compiled by the
Yellow River Conservancy Commission, and decided that the Diaokouhe River was the reserved flow path of the YR. The YR was artificially shifted in July 1964 near Yuwa, from its Shenxiangou course to the Diaokouhe course. The original Diaokouhe River flow path has no water flow to the ocean and ceased to transfer the river for nearly 37 years; landform features and the ecosystem changed greatly because of the changes in the hydrology, sand load, marine dynamics, and human activities. The freshwater wetland area and riverbed in the tail reaches of the Diaokouhe have been shrinking and drying up, undergoing a fast decrease in the ability to carry water and it has deteriorated salination and decreased biodiversity. Owing to a lack of freshwater and sand supply, the seawater continued to intrude and the coastal line retreated seriously. During 1976 to 2009, the DKHNR, which covers an area of $485 \mathrm{~km}^{2}$ because 2009 has retreated $10 \mathrm{~km}$ and eroded, and the oil well that is located in DKHNR and the seawater intrusion are severe threats to the water quality.

From July 2002 to June 2008, tests on seven times the amount of water and sediment that is stated in the regulations of the YR have been conducted. The change in the water and sediment conditions would inevitably have an impact on the ecosystem of the YRD (Bai et al. 2012). In 2009, the State Council formally approved the Yellow River Delta High Ecological Economic Zone Development Planning and noted that the Central Government should stabilize the current flow path of the YR and reuse the abandoned Diaokouhe river course. The Yellow River Conservancy Commission has conducted ecological transfer water engineering during the 10th flow-sediment regulation regime in July 2010 of the flood season to restore the estuarine ecosystem and wetland landscape in the abandoned Diaokouhe flow path of the tail reaches of the YR and to restore the function of transferring water and sand. The commission also aims to explore the alternate flow course use model of the Diaokouhe River reserved path and the current Qingshuigou flow path, to improve the strategy implemented and the estuarine governance, prevent the flow path of Diaokouhe from continuing to shrink, ensure estuarine flood control safety, and ameliorate the wetland areas from withering further.

During the flow-sediment regulation periods in 2010, 2011, 2012, and 2013, the transfer of water continued for 4 years in the Diaokouhe River and reduced the ecological degradation trend in the northern wetland region of the YR estuary. The transferred water volume was 36.20 million $\mathrm{m}^{3} ; 2.73$ million $\mathrm{m}^{3}$ flowed into the sea, and most of the 


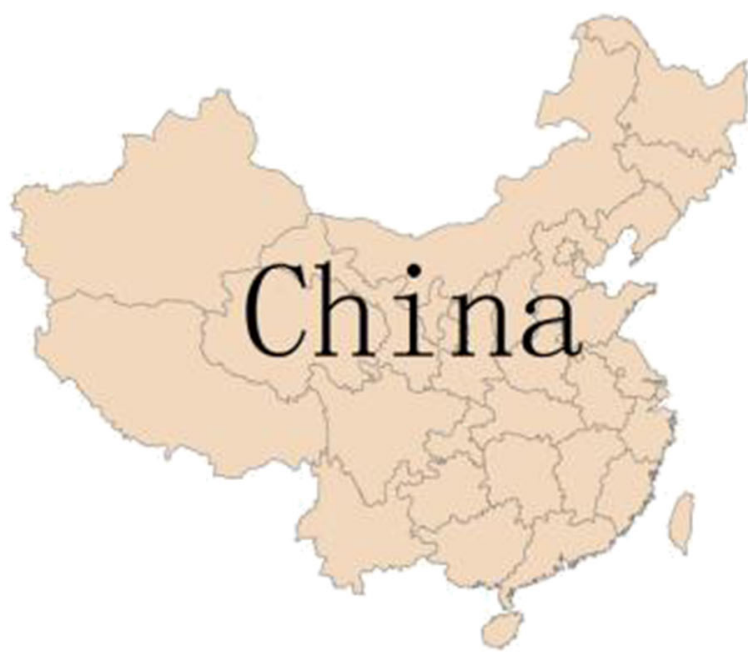

Yiqianer NR

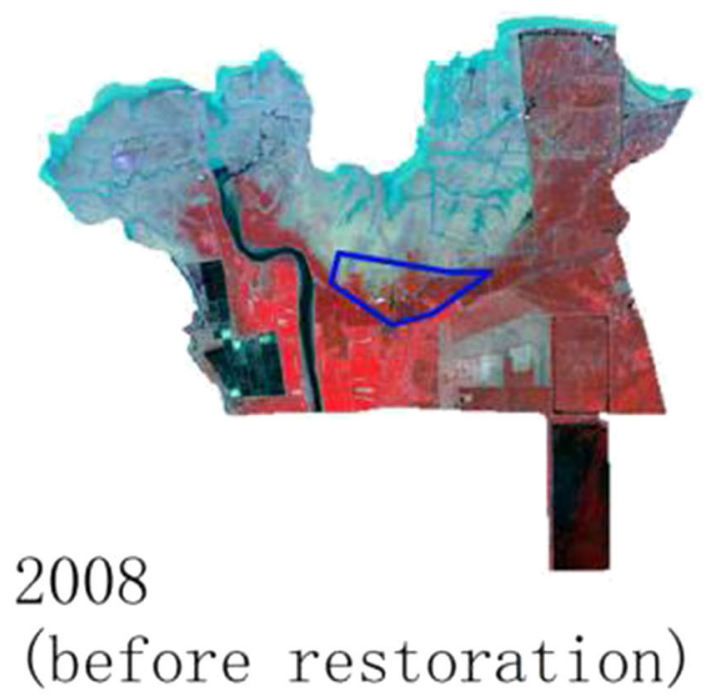

Fig. 1 The location of the study area

water has flowed into the DKHNR and riverbank. Moreover, the Diaokouhe flow path restoration has increased the water surface area by $526 \mathrm{hm}^{2}$, and approximately $437 \mathrm{hm}^{2}$ of the degraded wetland has been improved (Fig. 2). The soil salinity in the core restoration areas of the different vegetation communities along the Diaokouhe flow path has been decreasing, especially at depths of 0 to $30 \mathrm{~cm}$. Moreover, the surface soil water content has increased. Areas of Phragmites have increased from 10,000 to 22,000 ha. The water surface has increased
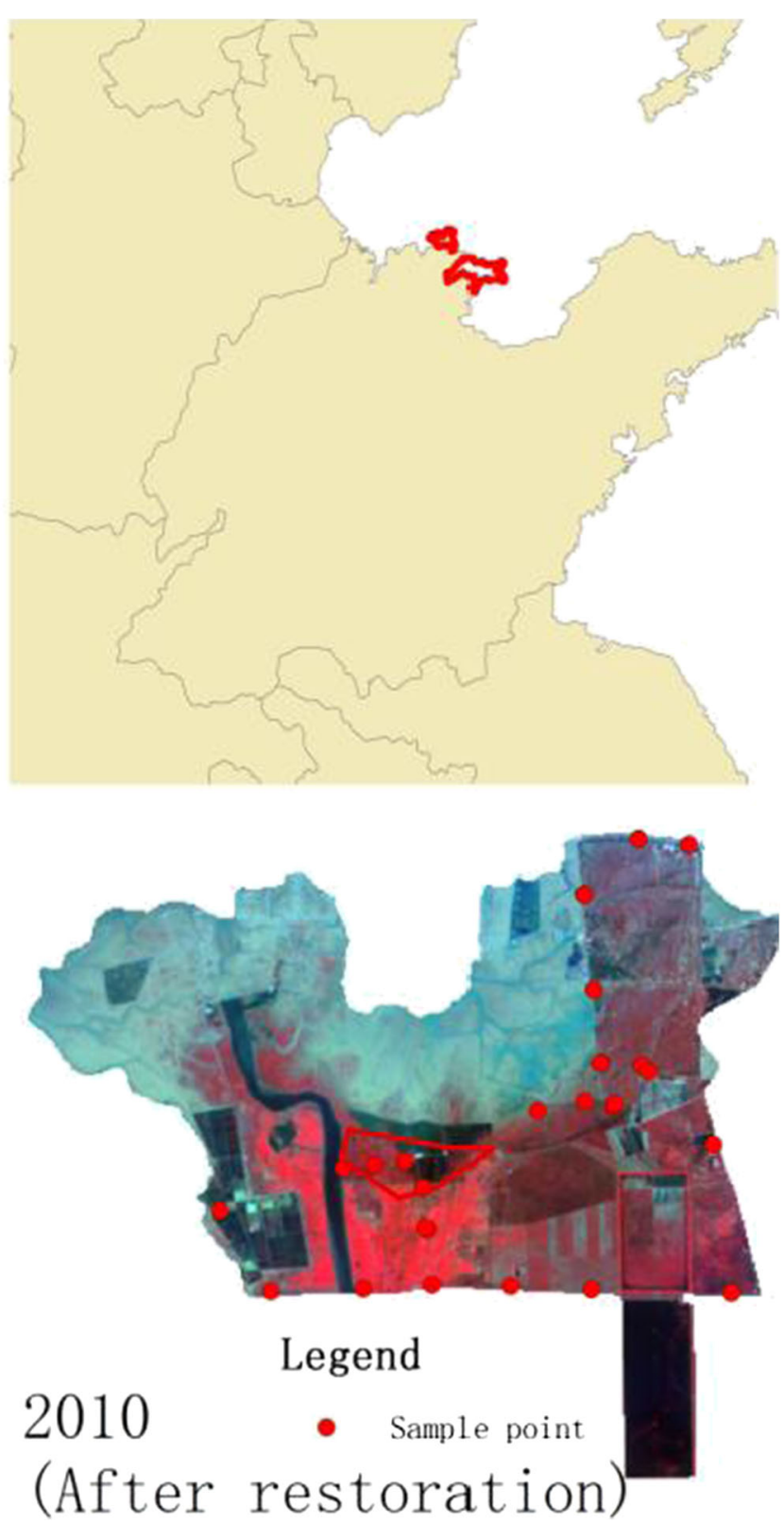

from 15 to $60 \%$, and the vegetation coverage has increased by $10 \%$ since the water transfer was initiated. The number of plant types has increased from 13 before the water transfer to 17 in 2010 and 26 in 2011. Furthermore, the number of aquatic birds has increased to 4,700 in 2010 and 12,000 in 2011 . The underground water level has continued to increase in the tail reaches of the Diaokouhe River, increasing by $20 \mathrm{~cm}$ in $2010 .^{2}$

\footnotetext{
$\overline{2}$ http://www.dzwww.com/finance/sdcj/201201/t20120105_ 6852712.html
} 

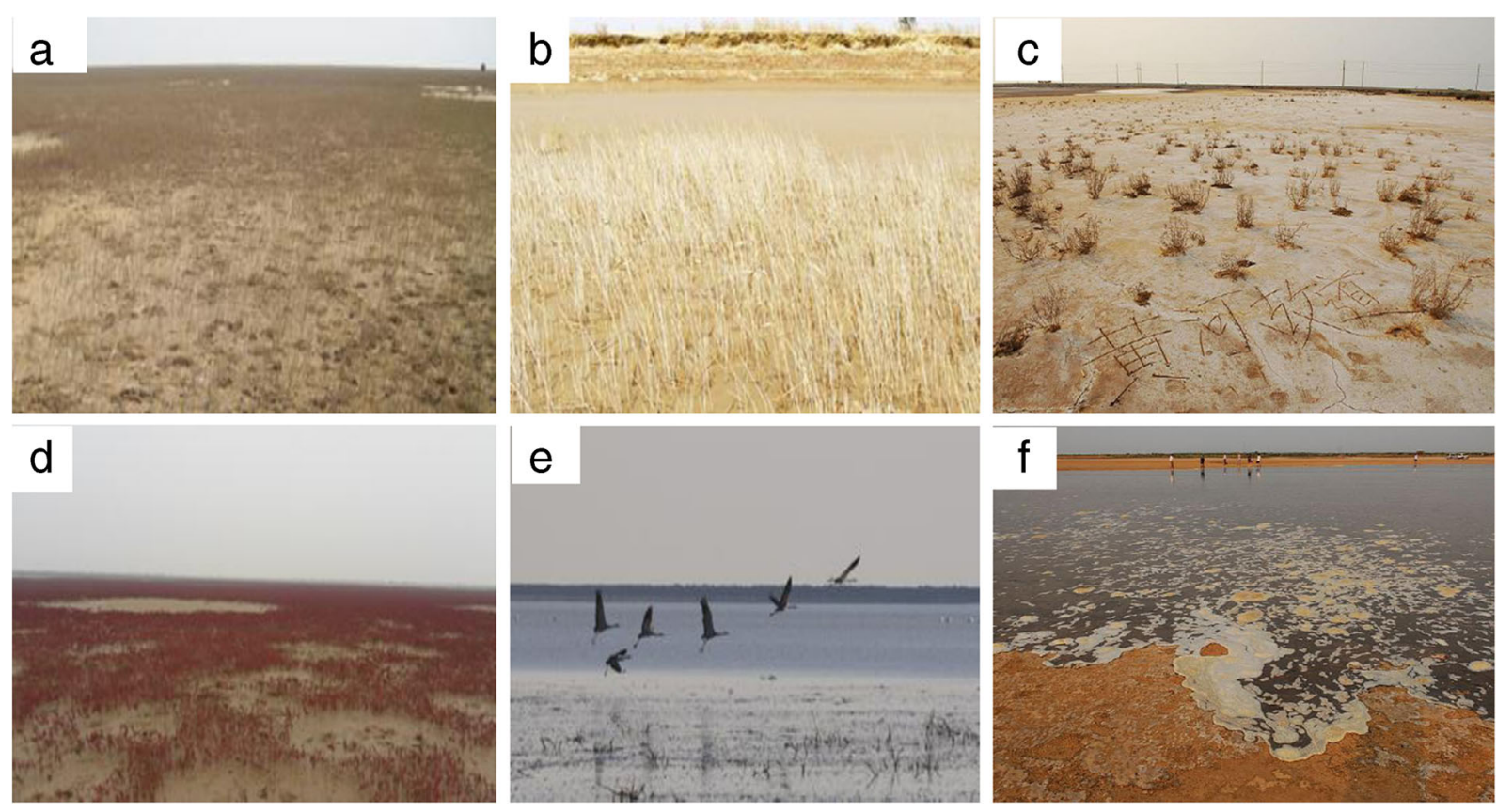

Fig. 2 The landscape before and after the transfer water project. a-c Before the transfer water project, while $\mathbf{d}-\mathbf{f}$ after the project. Source: http://www.sdhh.gov.cn/ztgz/stds/07/10009.shtml

\section{Sample collection}

During 2010, 28 soil profiles of 84 samples were obtained at depth intervals of 0-20, 20-40, and 40-60 cm. Samples that weighed $2 \mathrm{~kg}$ from three different locations with three replicates were collected at each plot using a stainless steel trowel. The replicated samples were mixed together at each location to form a composite sample. The land-use types are mudflat (MU), reed swamp (RS), thin reed (TR), forest (FO), arable land (AL), and Suaeda heteroptera (SH). All of the soil samples were placed in polyethylene bags and brought to the lab, where they were air-dried at room temperature for 3 weeks. The soil was oven dried at $105^{\circ} \mathrm{C}$ for $24 \mathrm{~h}$ and was weighed to determine the soil bulk density and moisture content. The air-dried soil was ground and passed through a 2-mm nylon sieve to remove coarse debris. The soil samples were then ground with a mortar and pestle until all of the particles passed through a $0.15-\mathrm{mm}$ nylon sieve, to analyze the soil chemical properties (Bai et al. 2011a).

\section{Analytical methods}

To analyze the total concentration of $\mathrm{As}, \mathrm{Cd}, \mathrm{Cu}, \mathrm{Pb}, \mathrm{Zn}$, $\mathrm{Ni}$, and $\mathrm{Cr}$, samples were digested by a HCIO4-HNO3-HF mixture in Teflon tubes at $160{ }^{\circ} \mathrm{C}$ for $6 \mathrm{~h}$ in an oven. The concentrations were transferred, and finally, $10 \mathrm{ml}$ of $10 \%$ $\mathrm{HNO}_{3}$ was used to rinse thoroughly for a complete transfer of the concentrations. The solution of the digested sample was analyzed by inductively coupled plasma-atomic emission spectrometry (ICP/AES). Quality assurance and control were assessed using duplicates, method blanks, and standard reference materials (GBW07401) from the Chinese Academy of Measurement Sciences for each batch sample (1 blank and 1 standard for each of 10 samples). To ensure the accuracy and precision of the experimental results, two standard reference materials, GSS-2-1 and GSS-2-2, were used as the quality control samples (Zhang et al. 2013). The standard deviation of As, $\mathrm{Cd}, \mathrm{Cr}, \mathrm{Cu}, \mathrm{Ni}, \mathrm{Pb}$, and $\mathrm{Zn}$ are 0.18, 0.01, 0.08, 0.74, 0.47, 0.54 , and 1.74 , respectively. The recoveries of samples that were spiked with standards ranged from 95 to $105 \%$. Duplicated samples were performed simultaneously for $5 \%$ of the soil samples, and the standard deviation showed a range of within $7 \%$. Soil organic carbon (SOC) was measured using dichromate oxidation and was determined by a CHNOS Elemental Analyzer (Bai et al. 2012). The total nitrogen concentration was determined by dry combustion using an elemental analyser, with a combustion temperature of $950{ }^{\circ} \mathrm{C}$ and a reduction temperature of $640^{\circ} \mathrm{C}$. The soil salinity was determined in the supernatant of 1:5 soil water mixtures (Bai et al. 2011b). 
The CF and PLI are introduced to assess the degree of anthropogenic metal contamination (Raj and Jayaprakash 2008). The CF for each metal is the ratio of the measured concentration to the natural abundance. The background value is determined through the soil survey in Shandong Province in the 1990s. Moreover, the CF is used to classify the extent of pollution into four grades for monitoring the pollution of specific metals over time. The CF is defined as follows:

$\mathrm{CF}=\frac{\mathrm{Me}_{\text {sample }}}{\mathrm{Me}_{\text {baseline }}}$

The calculated CFs were classified into four groups (Pekey et al. 2004):

\section{$\mathrm{CF} \leq 1 \quad$ low contamination factor}

$1<\mathrm{CF} \leq 3$ moderate contamination factor

$3<\mathrm{CF} \leq 6$ considerable contamination factor

$\mathrm{CF}>6$ very high contamination factor

The PLI was then applied to determine the integrated pollution status of the combined toxicant groups at the sampling stations and to assess the mutual pollution effect from different locations by various elements (Magesh et al. 2013). The PLI is determined as the $n$th root of the product of the $n$ contamination factors $(\mathrm{CF} n)$ :

$\mathrm{PLI}=(\mathrm{CF} 1 \times \mathrm{CF} 2 \times \mathrm{CF} 3 \times \cdots \mathrm{CFn})^{1 / n}$,

where CFn is the sampled concentration of metal $n$. The PLI values are interpreted into two pollution levels: polluted conditions (PLI $>1$ ) and unpolluted conditions $(\mathrm{PLI}<1)$.

After obtaining the metal concentrations, the $I_{\text {geo }}$ was used to quantitatively measure the metal pollution (ZamaniAhmadmahmoodi et al. 2013). The $I_{\text {geo }}$ was first introduced by Müller (1981) to compare present-day heavy metal concentrations with pre-civilized background values for understanding lithogenic effects. Therefore, the index can be used to distinguish the effects of human activities on the environment. The $I_{\text {geo }}$ is expressed as follows:

$I_{\text {geo }}=\log _{2} \frac{C_{n}}{1.5 \times B_{n}}$,

where $C_{n}$ is the concentration of the measured element $n$ and $B_{n}$ is the baseline value of a metal $n$-geochemical baseline value of a given element $n$. The geochemical baseline was obtained from the dataset of the national soil survey in Shandong Province. The constant 1.5 is introduced to minimize the potential effects of variations in the background values that could be attributed to lithological
Table 2 Scale of the pollution intensity for the geoaccumulation index values $\left(I_{\text {geo }}\right)$ classes with respect to the soil quality

\begin{tabular}{lll}
\hline$I_{\text {geo }}$ & $I_{\text {geo }}$ class & Pollution intensity (sediment quality) \\
\hline$>5$ & 6 & Very highly polluted \\
$4<I_{\text {geo }} \leq 5$ & 5 & Highly polluted to very highly polluted \\
$3<I_{\text {geo }} \leq 4$ & 4 & Highly polluted \\
$2<I_{\text {geo }} \leq 3$ & 3 & Moderately polluted to highly polluted \\
$1<I_{\text {geo }} \leq 2$ & 2 & Moderately polluted \\
$0<I_{\text {geo }} \leq 1$ & 1 & Unpolluted to moderately polluted \\
$\leq 0$ & 0 & Unpolluted \\
\hline
\end{tabular}

Zamani-Ahmadmahmoodi et al. (2013)

variations (Gao et al. 1998; Ghrefat et al. 2011). The sevenlevel classification of $I_{\text {geo }}$ is defined as in Table 2 (Müller 1981; Macias et al. 2006; Zamani-Ahmadmahmoodi et al. 2013). $I_{\text {geo }}$ has been calculated using background values for world crustal average metal concentrations as presented by Wedepohl (1995).

Multivariable statistics analyses, such as factor analysis (FA) and cluster analysis (CA), have been frequently applied to identify pollution sources and quantify their contributions (Singh et al. 2004; Zhang et al. 2009a, b). Pearson correlation was conducted to reveal the relationship between soil properties and heavy metals and to identify the pollution sources (Chandra et al. 2013; Zhang et al. 2014). Cluster analysis assisted in identifying relatively homogeneous groups of variables, using an algorithm that starts with each variable in a separate cluster and combines clusters until only one is left. One-way ANOVA was conducted to evaluate whether the vertical distribution of each heavy metal differed significantly between different land use types. Data were processed using the Statistical Program for Social Sciences (SPSS Version 17.0) statistical software.

\section{Results and discussion}

Relationship between trace elements and soil properties

Table 3 shows the range, average, and standard deviation of the $\mathrm{As}, \mathrm{Cd}, \mathrm{Cr}, \mathrm{Cu}, \mathrm{Ni}, \mathrm{Pb}, \mathrm{Zn}$, and SOC concentrations for the depths of 0-20, 20-40, and 40-60 cm soil in the DKHNR. The mean value of As is $8.09 \mathrm{mg} / \mathrm{kg}$, and the range is $4.04-12.62 \mathrm{mg} / \mathrm{kg}$. The concentrations of $\mathrm{Cd}$ are relatively low, with a mean value of $0.034 \mathrm{mg} / \mathrm{kg}$. The mean concentration of $\mathrm{Cr}$ is $17.41 \mathrm{mg} / \mathrm{kg}$, and the range is 


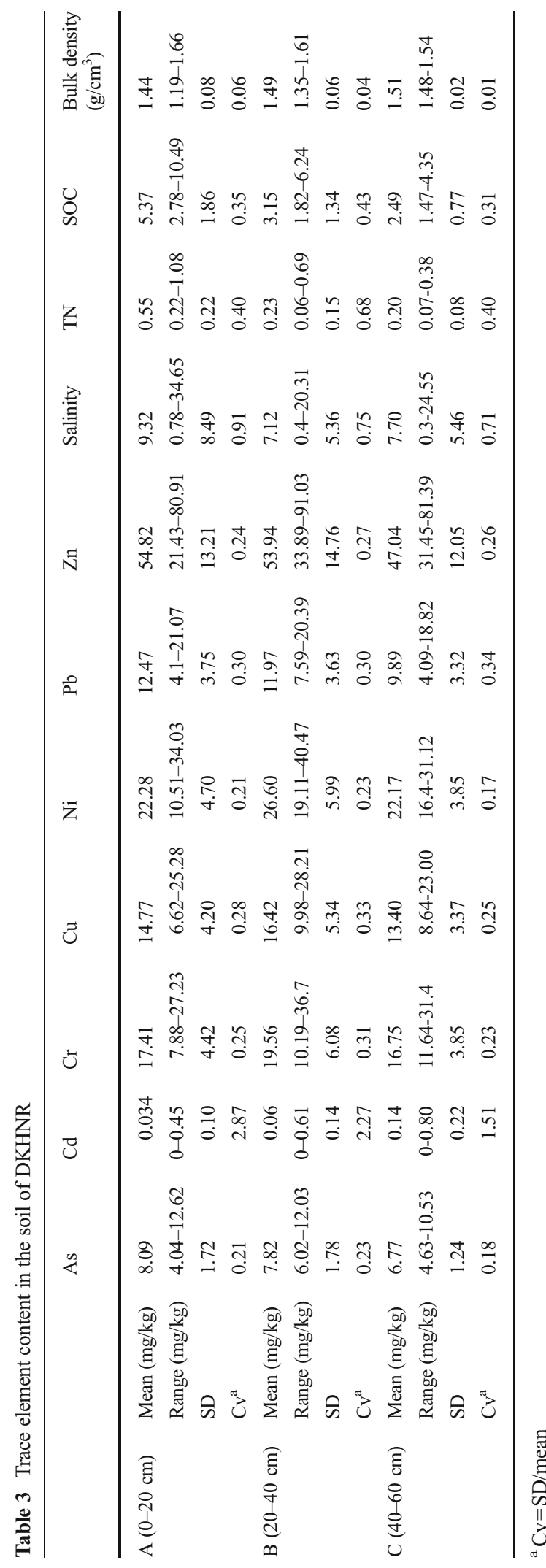

$7.88-27.23 \mathrm{mg} / \mathrm{kg}$. The coefficient of variation $(\mathrm{Cv})$ of As, $\mathrm{Cd}, \mathrm{Cr}, \mathrm{Cu}, \mathrm{Ni}, \mathrm{Pb}$, and $\mathrm{Zn}$ are 0.21, 2.87, 0.25, 0.28, 0.21, 0.30 , and 0.24 , respectively, while the mean values of these heavy metals are 8.09, 0.034, 17.41, 14.77, 22.28, 12.47, and $54.82 \mathrm{mg} / \mathrm{kg}$. The concentrations of $\mathrm{As}, \mathrm{Pb}$, and $\mathrm{Zn}$ continue to decrease in the three layers, while the concentration of Cd will increase with the depth of the soil. $\mathrm{Cd}$ had the highest spatial variability, with a coefficient of variation of 2.87 in the first layer, 2.27 in the second layer, and 1.51 in the bottom layers. The mean concentrations of all of the trace elements did not exceed their counterpart background values for Shandong Province. Specifically, the mean concentrations were approximately 87.04, 39.97, $26.38,61.54,86.34,48.32$, and $86.33 \%$ of the background values for $\mathrm{As}, \mathrm{Cd}, \mathrm{Cr}, \mathrm{Cu}, \mathrm{Ni}, \mathrm{Pb}$, and $\mathrm{Zn}$, respectively. In general, deep soils contain older and a larger proportion of recalcitrant organic matter than surface soil. Therefore, the relationships between the SOC content and environmental factors tend to be weaker along the soil profile. Because the environmental factors have less of an influence at larger depths, the SOC content in the deep soil layers could be more strongly determined by carbon inputs from the surface layer (Hu et al. 2013a; Dou et al. 2013). Moreover, the $\mathrm{Pb}$ concentrations that were measured in all of the soil samples were below level II of GB 15618-2002 (Soil Environmental Quality Standard), which indicates that the soils were not polluted. The heavy metal frequency histograms are provided in Fig. 3. These findings suggest that $\mathrm{As}, \mathrm{Cr}, \mathrm{Cu}, \mathrm{Ni}, \mathrm{Pb}$, and $\mathrm{Zn}$ were observed most often with moderate concentrations, whereas $\mathrm{Cd}$ was observed most often with low concentrations.

Vertical distribution of heavy metals in typical soil profiles

Figure 4 illustrates the distribution of heavy metal concentrations with depth for different land-use types. Usually, these concentrations fluctuated with increasing depth. Substantial $\mathrm{Cr}, \mathrm{Cu}, \mathrm{Ni}, \mathrm{Pb}$, and $\mathrm{Zn}$ accumulation in Reed swamp at depths of $20-40 \mathrm{~cm}(P<0.05)$ was observed. The green line represents the threshold of the Class I. Heavy metals usually decreased with depth, which indicates recent heavy metal pollution. The concentrations of As in the RS and SH surface layers $(0-20 \mathrm{~cm})$ were slightly higher than those at other sampling sites. The heavy metal concentrations in $\mathrm{RS}$ and $\mathrm{SH}$ were higher than in the other soil layers. Furthermore, the different soil depths exhibited similar concentration characteristics (i.e., $\mathrm{Cr}, \mathrm{Cu}, \mathrm{Ni}, \mathrm{Pb}$, and $\mathrm{Zn}$ ). 

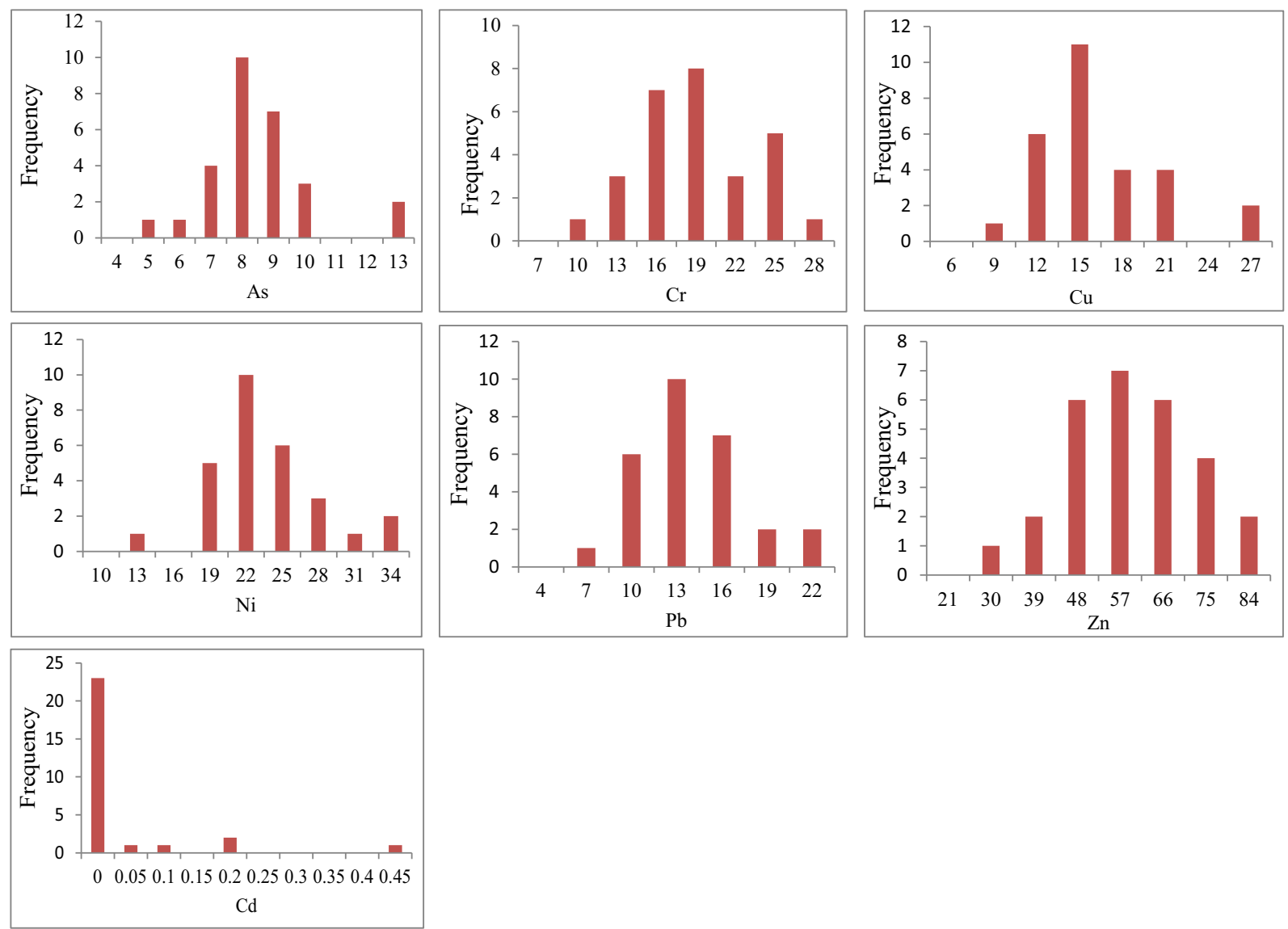

Fig. 3 Heavy metal frequency distributions

There were no pronounced differences in the trace metal levels at $40-60 \mathrm{~cm}$ layers $(P>0.05)$. It should be noted that $\mathrm{Pb}$ concentrations were higher in the three layers than the mean concentration in YRD $(9.29 \mathrm{mg} / \mathrm{kg})$ (Cui et al. 2011) and lower than in the Pearl River Estuary (32.23 mg/kg) (Bai et al. 2011d) and Baiyangdian Lake (30.72 mg/kg) (Gao et al. 2013). No apparent difference in the trace metal concentrations within each layer was observed $(P>0.05)$, which indicates that similar trace metal levels were observed in these two wetlands.

The vertical distribution of heavy metals was decomposed into three $20 \mathrm{~cm}$ intervals for each $60 \mathrm{~cm}$ profile. The vertical distribution was quantified using the ratio of the heavy metal concentration in the surface layer $(0-20 \mathrm{~cm})$ to the concentration at a depth of $60 \mathrm{~cm}$ (Wang and Chen 2009). No significant differences in the heavy metal vertical distributions were observed between the different land-use types. However, SOC exhibited a decreasing trend with increasing depth in some plots. Furthermore, agriculture in the DKHNR has traditionally been a dominant economic driving force and was relatively less affected by industrial activities compared to other coastal areas in China. Until recently, the YRD remained in a low exploitation state, which could explain the low heavy metal concentrations at the surface. As a major source of carbon inputs into the soil, vertical concentrations of heavy metals should play an important role in determining heavy metal vertical distributions.

Identification potential of natural and anthropogenic sources

Because factor analysis considerably reduces the number of variables and can detect the relationships between the metals, it has been proven to be an effective tool for heavy metal source identification (Han et al. 2006; Varol 2011; Panda et al. 2010). PCA analysis was applied to help identify heavy metal sources (Tables 4, 5, and 6). A 

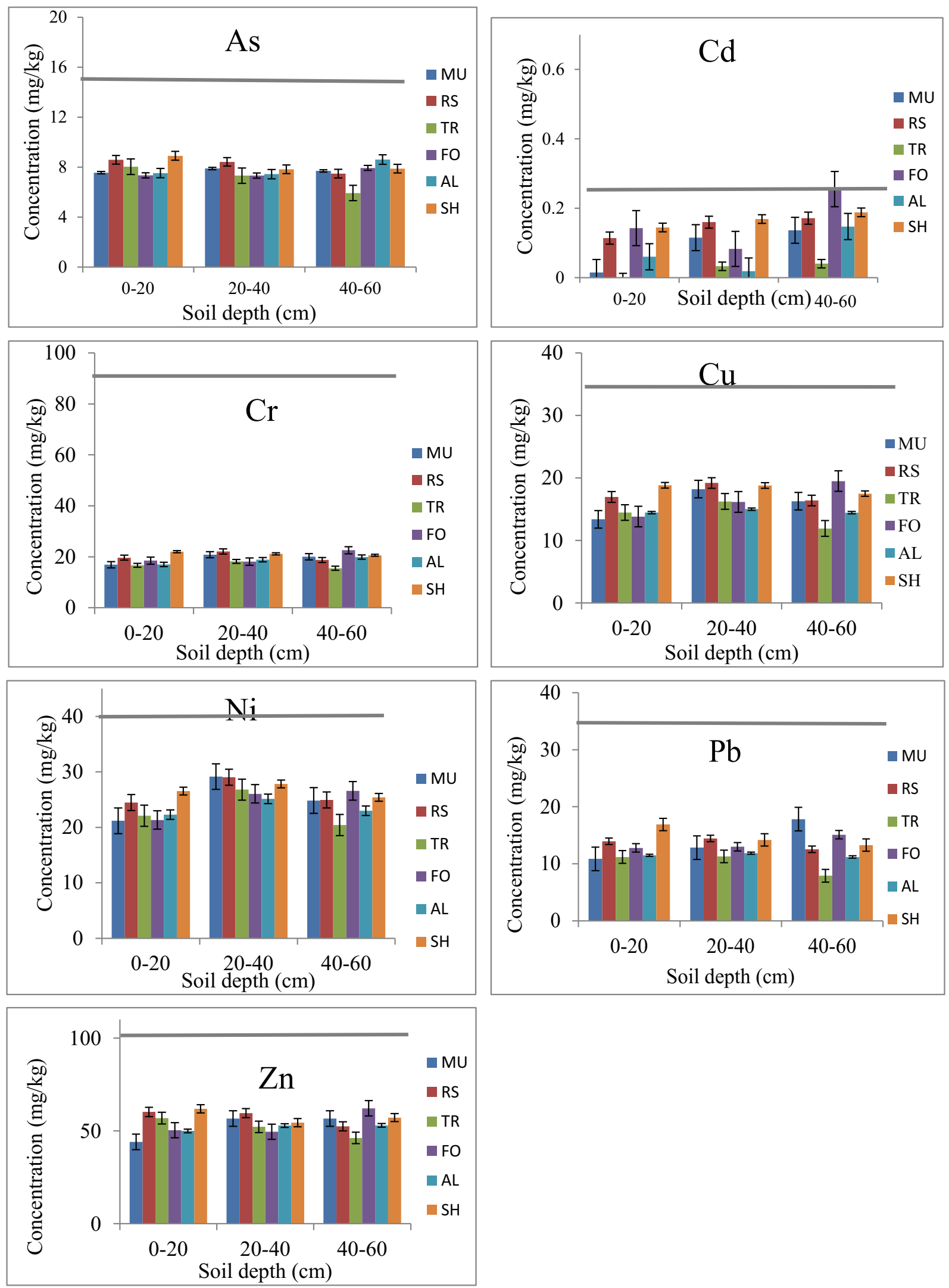
Fig. 4 Vertical distribution of heavy metals in soils that have different land-use types, i.e., $M U$ (mudflat), $R S$ (reed swamp), $T R$ (thin reed), $F O$ (forest), $A L$ (arable land), and $S H$ ( $S$. heteroptera). The green line represents the threshold of the class I, As is $15 \mathrm{mg} / \mathrm{kg}, \mathrm{Cd}$ is $0.2 \mathrm{mg} / \mathrm{kg}, \mathrm{Cr}$ is $90 \mathrm{mg} / \mathrm{kg}, \mathrm{Cu}$ is $35 \mathrm{mg} / \mathrm{kg}$, Ni is $40 \mathrm{mg} / \mathrm{kg}, \mathrm{Pb}$ is $35 \mathrm{mg} / \mathrm{kg}$, and $\mathrm{Zn}$ is $100 \mathrm{mg} / \mathrm{kg}$

varimax rotation of the principal components or factors was used to clarify the results and to provide a simpler and more meaningful representation of the underlying factors because the rotation reduces the contribution of variables that have low significance and increases the contribution of the more significant variables (Chandra et al. 2013). Kaiser-Meyer-Olkin (KMO) and Bartlett's results were 0.873 and $264.634(d f=21, P<0.01)$ in the first soil layer, 0.875 and 321.247 in the second layer, and 0.864 and 258.418 in the bottom layer, which indicates that the PCA is useful in reducing the number of dimensions.

Eigenvalues that were greater than 1 and that provided a cumulative variance of more than $85 \%$ were retained in the original dataset (Bai et al. 2012). The principal components were then rotated using the varimax normalization method; the results are reported as factor loadings of the rotated matrix, which are given in Tables 4, 5, and 6. For the first layers, two principle components (PCs) explained $91.52 \%$ of the total variance based on the retained eigenvalues (eigenvalue $>1$ ). The first principal component can explain $76.35 \%$ of the variance, and the second principal component can explain $15.17 \%$ of the variance. The seven PCs explained $100 \%$ of the total variance based on the retained eigenvalues. These PCs were extracted and the other PCs were discarded. First, all six heavy metals, i.e., Ni, $\mathrm{Cu}, \mathrm{As}, \mathrm{Zn}, \mathrm{Cr}$, and $\mathrm{Pb}$, were strongly associated with PC1 (positive loading), especially $\mathrm{Ni}$, which had a weight of 0.98 ; this weight reflects its lithogenic origin (Table 4). Therefore, PC1 could reflect the contribution of natural geological sources of metals into the coastal sediments. The rotated component matrix indicates that most of the heavy metals were closely associated with $\mathrm{PC} 1$, which can be termed the "lithogenic factor" ( $\mathrm{Hu}$ et al. 2013a). The PCA results show that Cd largely diverged from group 2 and that PC2 is highly associated with $\mathrm{Cd}$. Therefore, PC2 could represent anthropogenic sources of metal pollution. Moreover, $\mathrm{Cd}$ could be a result of anthropogenic inputs from riverine sources, which contain both a natural component and a substantial proportion of anthropogenic waste that is ultimately transported to estuaries and continental margins of the oceans.

For the second layers $(20-40 \mathrm{~cm})$, heavy metals, such as $\mathrm{Cu}, \mathrm{Zn}, \mathrm{As}, \mathrm{Pb}, \mathrm{Ni}$, and $\mathrm{Cr}$, form a closely related group that dominates $\mathrm{PC} 1$, explaining $80.67 \%$ of the total variance in the second soil layer (Table 5). Moreover, PC2, which explained $14.42 \%$ of the total variance, also exhibited highly positive factor loadings on Cd. The two PCs explained $95.09 \%$ of the total variance. $\mathrm{PC} 1$ was also strongly and positively correlated with $\mathrm{Cu}, \mathrm{Zn}, \mathrm{As}, \mathrm{Pb}, \mathrm{Ni}$, and $\mathrm{Cr}$ and can be defined as an anthropogenic component due to the presence of higher levels of these metals in the sampled soil relative to other coastal regions in China. PC2 could primarily represent anthropogenic sources (Fang et al. 2009). In

Table 4 The total variance explained and the rotated component matrix of the first soil layer $(0-20 \mathrm{~cm})$

\begin{tabular}{|c|c|c|c|c|c|c|c|c|c|}
\hline & \multicolumn{4}{|c|}{ Initial eigenvalues } & \multicolumn{3}{|c|}{ Rotation sum of squared loadings } & \multicolumn{2}{|c|}{ Rotated component matrix } \\
\hline & $\begin{array}{l}\text { Total } \\
\text { Total }\end{array}$ & $\begin{array}{l}\% \text { of variance } \\
\text { riance explained }\end{array}$ & Cumulative $\%$ & Element & Total & $\%$ of variance & Cumulative $\%$ & $\mathrm{PC} 1$ & $\mathrm{PC} 2$ \\
\hline \multicolumn{10}{|c|}{ Principal component } \\
\hline 1 & 5.378 & 76.689 & 76.689 & $\mathrm{Ni}$ & 5.344 & 76.346 & 76.346 & 0.981 & -0.070 \\
\hline 2 & 1.038 & 14.827 & 91.516 & $\mathrm{Cu}$ & 1.062 & 15.171 & 91.516 & 0.973 & -0.081 \\
\hline 3 & 0.211 & 3.015 & 94.531 & As & & & & 0.968 & -0.020 \\
\hline 4 & 0.194 & 2.777 & 97.308 & $\mathrm{Zn}$ & & & & 0.940 & 0.048 \\
\hline 5 & 0.144 & 2.060 & 99.368 & $\mathrm{Cr}$ & & & & 0.918 & 0.052 \\
\hline 6 & 0.028 & 0.398 & 99.766 & $\mathrm{~Pb}$ & & & & 0.879 & -0.238 \\
\hline 7 & 0.016 & 0.234 & 100.000 & $\mathrm{Cd}$ & & & & -0.037 & 0.994 \\
\hline
\end{tabular}

Extraction method, principal component analysis; rotation method, Varimax 
Table 5 The total variance explained and the rotated component matrix of the second soil layer $(20-40 \mathrm{~cm})$

\begin{tabular}{|c|c|c|c|c|c|c|c|c|c|}
\hline & \multicolumn{4}{|c|}{ Initial eigenvalues } & \multicolumn{3}{|c|}{ Rotation sums of squared loadings } & \multicolumn{2}{|c|}{ Rotated component matrix } \\
\hline & $\begin{array}{l}\text { Total } \\
\text { Total v }\end{array}$ & $\begin{array}{l}\% \text { of variance } \\
\text { riance explained }\end{array}$ & Cumulative $\%$ & Elements & Total & $\%$ of variance & Cumulative & $\mathrm{PC} 1$ & $\mathrm{PC} 2$ \\
\hline \multicolumn{10}{|c|}{ Principal component } \\
\hline 1 & 5.647 & 80.674 & 80.674 & $\mathrm{Cu}$ & 5.647 & 80.670 & 80.670 & 0.985 & -0.019 \\
\hline 2 & 1.009 & 14.420 & 95.094 & $\mathrm{Zn}$ & 1.010 & 14.424 & 95.094 & 0.984 & -0.014 \\
\hline 3 & 0.183 & 2.616 & 97.710 & As & & & & 0.977 & -0.035 \\
\hline 4 & 0.061 & 0.868 & 98.578 & $\mathrm{~Pb}$ & & & & 0.977 & -0.041 \\
\hline 5 & 0.052 & 0.743 & 99.321 & $\mathrm{Ni}$ & & & & 0.957 & -0.005 \\
\hline 6 & 0.036 & 0.508 & 99.830 & $\mathrm{Cr}$ & & & & 0.940 & 0.086 \\
\hline 7 & 0.012 & 0.170 & 100.000 & $\mathrm{Cd}$ & & & & -0.005 & 0.999 \\
\hline
\end{tabular}

Extraction method, principal component analysis; rotation method, Varimax

the rotated principal component matrix, $\mathrm{PC} 1$ was positively correlated with $\mathrm{Cu}, \mathrm{Zn}, \mathrm{As}, \mathrm{Pb}, \mathrm{Ni}$, and $\mathrm{Cr}$. PC2 was positively correlated with $\mathrm{Cd}$. This finding implies that $\mathrm{Cd}$ sources could be different from the sources of the other trace elements. The correlation analysis also suggests that there were significant correlations between As and $\mathrm{Cr}, \mathrm{Cu}, \mathrm{Ni}, \mathrm{Pb}$, and $\mathrm{Zn}$; a poor correlation was found between $\mathrm{Cd}$ and the other trace elements. Therefore, Cd can be regarded as an exogenous metal (Bai et al. 2012). Because of rapid agricultural development upstream of the YRD, substantial applications of agrochemicals and fertilizers have contributed to a large increase in heavy metal concentrations.

In the bottom soil layer $(40-60 \mathrm{~cm})$, the first principal component explained $80.20 \%$ of the total variance and the second principal component explained $11.44 \%$ of the total variance. The two principal components explained $91.64 \%$ of the total variance. In the component matrix, only one PC was detected, and it exhibited highly positive factor loadings on $\mathrm{Ni}, \mathrm{Cu}, \mathrm{As}, \mathrm{Zn}, \mathrm{Cr}$, and $\mathrm{Pb}$, and the loading for $\mathrm{Cd}$ was only 0.523 (Table 6). These metals, i.e., $\mathrm{Cu}, \mathrm{As}, \mathrm{Zn}, \mathrm{Cr}$, $\mathrm{Ni}$, and $\mathrm{Pb}$, were all associated with $\mathrm{PC} 1$ in the component matrix. This finding also indicates that all of the metals had the same source, which might be directly related to a lithogenic component because the variability of the concentrations appeared to be controlled by loess parent materials.

To reveal the possible associations between the variables, Pearson's correlation analysis was performed for the entire element concentration dataset. Table 7 shows

Table 6 The total variance explained and the rotated component matrix of the bottom soil layer $(40-60 \mathrm{~cm})$

\begin{tabular}{|c|c|c|c|c|c|c|c|c|}
\hline & \multicolumn{4}{|c|}{ Initial eigenvalues } & \multicolumn{3}{|c|}{ Rotation sums of squared loadings } & \multirow[b]{2}{*}{$\begin{array}{l}\text { Component } \\
\text { matrix } \\
\text { PC1 }\end{array}$} \\
\hline & $\begin{array}{l}\text { Total } \\
\text { Total } \mathrm{V}\end{array}$ & $\begin{array}{l}\% \text { of variance } \\
\text { nce explained }\end{array}$ & Cumulative \% & Elements & Total & $\%$ of variance & Cumulative & \\
\hline \multicolumn{9}{|c|}{ Principal component } \\
\hline 1 & 5.614 & 80.202 & 80.202 & $\mathrm{Cu}$ & 5.614 & 80.202 & 80.202 & 0.971 \\
\hline 2 & 0.800 & 11.435 & 91.637 & As & & & & 0.958 \\
\hline 3 & 0.276 & 3.947 & 95.584 & $\mathrm{Zn}$ & & & & 0.954 \\
\hline 4 & 0.136 & 1.938 & 97.522 & $\mathrm{Cr}$ & & & & 0.951 \\
\hline 5 & 0.090 & 1.281 & 98.803 & $\mathrm{Ni}$ & & & & 0.935 \\
\hline 6 & 0.063 & 0.905 & 99.708 & $\mathrm{~Pb}$ & & & & 0.890 \\
\hline 7 & 0.020 & 0.292 & 100.000 & $\mathrm{Cd}$ & & & & 0.523 \\
\hline
\end{tabular}

Extraction method, principal component analysis; rotation method, Varimax 
Table 7 Correlation coefficient matrices between soil heavy metal concentrations and soil properties for three different layers

\begin{tabular}{|c|c|c|c|c|c|c|c|c|c|c|c|}
\hline & As & $\mathrm{Cd}$ & $\mathrm{Cr}$ & $\mathrm{Cu}$ & $\mathrm{Ni}$ & $\mathrm{Pb}$ & $\mathrm{Zn}$ & Salinity & $\mathrm{TN}$ & SOC & Bulk density \\
\hline \multicolumn{12}{|c|}{ The first layer $(0-20 \mathrm{~cm})$} \\
\hline As & 1 & & & & & & & 0.067 & 0.150 & 0.322 & 0.019 \\
\hline $\mathrm{Cd}$ & -0.059 & 1 & & & & & & -0.222 & 0.177 & 0.166 & -0.200 \\
\hline $\mathrm{Cr}$ & $0.830^{* *}$ & -0.004 & 1 & & & & & 0.213 & 0.143 & 0.303 & -0.078 \\
\hline $\mathrm{Cu}$ & $0.965^{* *}$ & -0.118 & $0.872^{* *}$ & 1 & & & & 0.168 & 0.228 & $0.371^{*}$ & -0.004 \\
\hline $\mathrm{Ni}$ & $0.966^{* *}$ & -0.107 & $0.873^{* *}$ & $0.981^{* *}$ & 1 & & & 0.102 & 0.169 & 0.310 & 0.015 \\
\hline $\mathrm{Pb}$ & $0.813^{* *}$ & -0.233 & $0.765^{* *}$ & $0.836^{* *}$ & $0.851^{* *}$ & 1 & & 0.098 & $0.360^{*}$ & $0.487^{*}$ & -0.196 \\
\hline $\mathrm{Zn}$ & $0.900^{* *}$ & -0.001 & $0.840^{* *}$ & $0.868^{* *}$ & $0.897^{* *}$ & $0.797^{* *}$ & 1 & -0.117 & 0.179 & $0.353^{*}$ & -0.137 \\
\hline \multicolumn{12}{|c|}{ The second layer $(20-40 \mathrm{~cm})$} \\
\hline As & 1 & & & & & & & 0.076 & $0.791^{* *}$ & $0.777^{* *}$ & -0.665 \\
\hline $\mathrm{Cd}$ & -0.040 & 1 & & & & & & -0.109 & 0.018 & -0.097 & 0.015 \\
\hline $\mathrm{Cr}$ & $0.926^{* *}$ & 0.070 & 1 & & & & & 0.189 & $0.755^{* *}$ & $0.717^{* *}$ & $-0.624^{*}$ \\
\hline $\mathrm{Cu}$ & $0.957^{* *}$ & -0.020 & $0.886^{* *}$ & 1 & & & & 0.149 & $0.780^{* *}$ & $0.780^{* *}$ & $-0.645^{*}$ \\
\hline $\mathrm{Ni}$ & $0.907^{* *}$ & -0.006 & $0.838^{* *}$ & $0.974^{* *}$ & 1 & & & 0.176 & $0.720^{* *}$ & $0.723^{* *}$ & $-0.555^{*}$ \\
\hline $\mathrm{Pb}$ & $0.945^{* *}$ & -0.044 & $0.899^{* *}$ & $0.954^{* *}$ & $0.927^{* *}$ & 1 & & 0.172 & $0.797^{* *}$ & $0.835^{* *}$ & $-0.656^{*}$ \\
\hline $\mathrm{Zn}$ & $0.953^{* *}$ & -0.019 & $0.926^{* *}$ & $0.961^{* *}$ & $0.925^{* *}$ & $0.962^{* *}$ & 1 & 0.148 & $0.811^{* *}$ & $0.805^{* *}$ & $-0.634^{*}$ \\
\hline \multicolumn{12}{|c|}{ The second layer $(40-60 \mathrm{~cm})$} \\
\hline As & 1 & & & & & & & 0.283 & $0.686^{*}$ & $0.807^{* *}$ & $-0.807^{* *}$ \\
\hline $\mathrm{Cd}$ & 0.511 & 1 & & & & & & 0.124 & 0.392 & 0.304 & -0.302 \\
\hline $\mathrm{Cr}$ & $0.890^{* *}$ & $0.478^{*}$ & 1 & & & & & 0.142 & $0.677^{*}$ & $0.788^{* *}$ & $-0.786^{*}$ \\
\hline $\mathrm{Cu}$ & $0.910^{* *}$ & 0.467 & $0.890^{* *}$ & 1 & & & & 0.121 & $0.810^{* *}$ & $0.850^{* *}$ & $-0.849^{* *}$ \\
\hline $\mathrm{Ni}$ & $0.872^{* *}$ & 0.405 & $0.831^{* *}$ & $0.967^{* *}$ & 1 & & & 0.121 & $0.807^{* *}$ & $0.823^{* *}$ & $-0.823^{* *}$ \\
\hline $\mathrm{Pb}$ & $0.855^{* *}$ & 0.292 & $0.869^{* *}$ & $0.811^{* *}$ & $0.778^{* *}$ & 1 & & 0.181 & $0.660^{*}$ & $0.819^{* *}$ & $-0.818^{* *}$ \\
\hline $\mathrm{Zn}$ & $0.888^{* *}$ & 0.395 & $0.913^{* *}$ & $0.936^{* *}$ & $0.886^{* *}$ & $0.832^{* *}$ & 1 & 0.248 & $0.711^{*}$ & $0.863^{* *}$ & $-0.861^{* *}$ \\
\hline
\end{tabular}

$* P<0.05$ (correlation is significant); $* * P<0.01$ (correlation is significant)

the correlation coefficient matrix between the heavy metals and soil properties in the abandoned wetlands. Significant and positive correlations $(P<0.01)$ were observed between $\mathrm{Cr}$ and $\mathrm{Ni}, \mathrm{Cr}$ and $\mathrm{Pb}, \mathrm{Cu}$ and $\mathrm{Pb}, \mathrm{Ni}$ and $\mathrm{Pb}$, and $\mathrm{Pb}$ and $\mathrm{Zn}$ due to anthropogenic activities, whereas no significant correlations were detected among other metals (Magesh et al. 2013). This finding indicates that these metals were associated with one another and might have common natural or anthropogenic sources. SOC exhibited a positive linear relationship with $\mathrm{Cu}, \mathrm{Pb}$, and $\mathrm{Zn}$ in the first soil layer $(0-20 \mathrm{~cm})$ $(P<0.05)$; $\mathrm{As}, \mathrm{Cr}, \mathrm{Cu}, \mathrm{Ni}, \mathrm{Pb}$, and $\mathrm{Zn}$ in the second layer $(20-40 \mathrm{~cm})$; and $\mathrm{As}, \mathrm{Cr}, \mathrm{Cu}, \mathrm{Ni}, \mathrm{Pb}$, and $\mathrm{Zn}$ in the third layer $(40-60 \mathrm{~cm})$. Moreover, SOC exhibited only a negative correlation with $\mathrm{Cd}(P<0.05)$, which was in the second and third layers. Some studies have shown that SOC can act as a major sink for heavy metals due to its strong capacity for metallic contaminants (Bai et al. 2011d). In this study, $\mathrm{Cu}$ was significantly correlated with SOC, which suggests that SOC is an important factor that controls the abundance of heavy metals. The results that were obtained from the PCA were confirmed by Pearson's correlation analysis.

CA can be used to further classify elements from different sources on the basis of similarities in their chemical properties. A dendrogram was constructed to assess the cohesiveness of the determined clusters and to more easily determine the correlations between the elements (Han et al. 2006). Spatial CA produces a dendrogram that has three groups, using the Euclidian distances in the first layer $(0-20 \mathrm{~cm})$, second layer $(20-40 \mathrm{~cm})$, and third layers $(40-60 \mathrm{~cm})$. Hierarchical cluster analysis was performed using War's method, with squared Euclidean distances as the criterion to form the heavy metal clusters. Generally, Euclidian distances in cluster analysis indicate a different origin from the other 
elements. Figure 5 shows three clusters in the first soil layer, two clusters in the second layer, and two clusters in the third layer. A highly joined cluster implies a common source or sources and the results agreed with the factor analysis. The results show that all of the classifications vary within the significance level because the sampling sites in each group have similar backgrounds and could be affected by relatively similar sources (Fig. 5). For the first soil layer (0-20 cm), most of the sampling sites contained groups $\mathrm{A}$ and $\mathrm{C}$, which exhibited lower metal concentrations than group B. The highest trace metal concentrations were found in group $\mathrm{B}$, which mainly resulted from point pollution sources. For the second soil layer, the highest metal concentration was also observed in group B.

Assessment of arsenic and heavy metal using $I_{\text {geo }}$

Every soil that was sampled contained natural heavy metals at background concentrations (Raj and Jayaprakash 2008; Karim et al. 2013; Chandra et al. 2013). Based on the soil background value, the possible enrichment of As and heavy metals in wetland soils was evaluated and is presented using geoaccumulation indices $\left(I_{\mathrm{geo}}\right)$ in Fig. 6 (Müller 1981). According to the Müller classification scale (1981), trace elements belong to the unpolluted category in all of the samples, although some deviation was observed depending on the specific metal and sampling location. Moreover, $\mathrm{As}, \mathrm{Cr}, \mathrm{Cu}, \mathrm{Ni}$, $\mathrm{Pb}$, and $\mathrm{Zn}$ exhibited lower $I_{\text {geo }}$ values, averaging less than 0 in the three soil layers, which indicates that the soils have remained unpolluted by these heavy metals. The $I_{\text {geo }}$ values of As in the surface soil from the DKHNR were -1.79 and -0.14 (average of -0.82 ) for the first layer, -1.21 and -0.21 (average of -0.87 ) for the second layer, and -1.59 and -0.41 (average of $-1.07)$ for the bottom layer. The $I_{\text {geo }}$ values for $\mathrm{Cr}$ were -3.65 to -1.86 (average of -2.55 ) for the first soil layer, -3.37 to -1.52 (average of -2.49 ) for the second layer, and -3.17 to -1.74 (average of -2.68 ) for the third layer. The averaged degree of metal pollution decreased in the following order: $\mathrm{As}>\mathrm{Ni}>\mathrm{Zn}>\mathrm{Cu}>\mathrm{Pb}>\mathrm{Cr}$ for the first soil layer, $\mathrm{Ni}>\mathrm{As}>\mathrm{Zn}>\mathrm{Cu}>\mathrm{Pb}>\mathrm{Cr}$ for the second layer, and $\mathrm{Ni}>\mathrm{As}>\mathrm{Zn}>\mathrm{Cu}>\mathrm{Pb}>\mathrm{Cr}$ for the bottom layer.
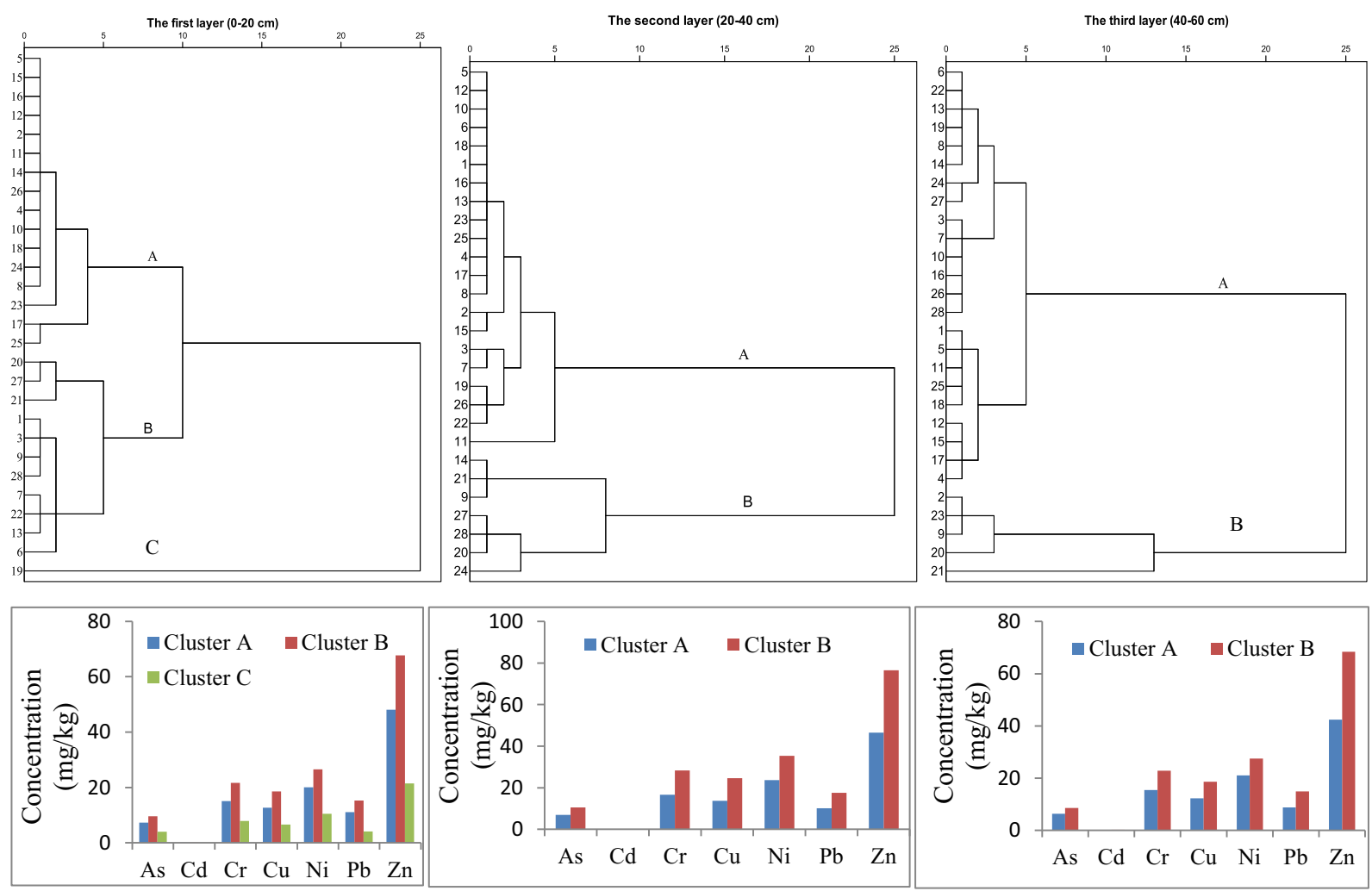

Fig. 5 Hierarchical dendrograms for seven heavy metals that were obtained using War's hierarchical clustering method (the distances reflect the degree of correlation between different heavy metals) 


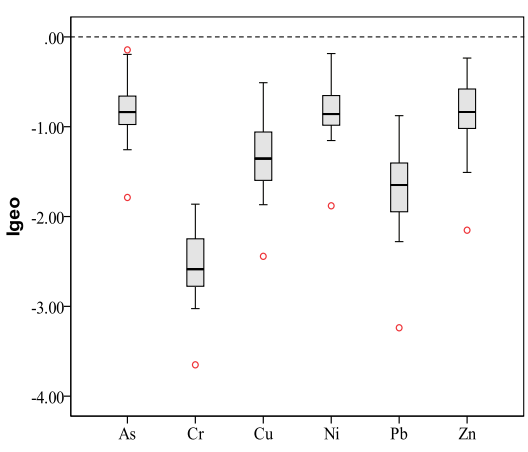

(a)

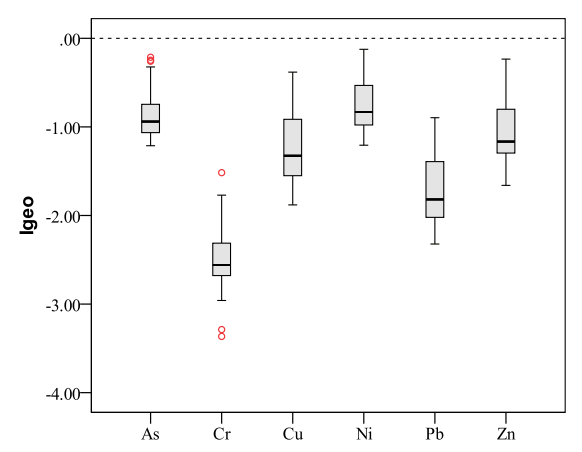

(b)

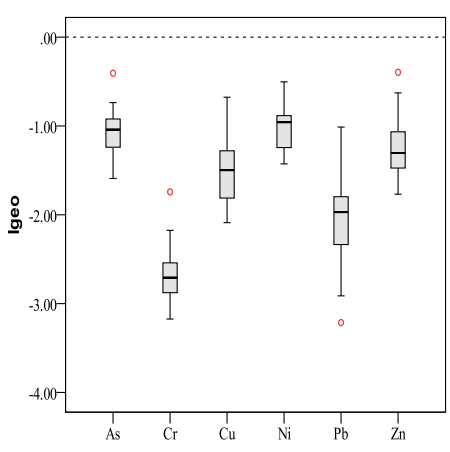

(c)

Fig. 6 Box-and-whisker plots of the geoaccumulaton indices for heavy metals of three different soil depths in DKHNR. a 0-20 cm; b 20$40 \mathrm{~cm}$; c $40-60 \mathrm{~cm}$. The $y$-axis is the geoaccumulation indices, and the $x$-axis is the heavy metal types

According to the Müller scale (Müller 1981), the $I_{\text {geo }}$ values indicate no pollution of the investigated metals as a whole, although some deviations are observed depending on each metal and the sampling location (Fig. 6) In general, Cd pollution sources were primarily due to land-based anthropogenic sources, including mining and fertilizers and pesticides used in agricultural activities (Nobi et al. 2010).

The extent of contamination was earlier quantified by comparing the observed concentrations with uncontaminated natural background values for a specific metal (Macias et al. 2006). To understand the heavy metal enrichment, the CF was calculated for all of the studied metals. The results show that only $\mathrm{Ni}$ in the second layer was enriched, whereas all of the other metals remained within a low contamination state. Thus, with respect to the background concentrations, the soils were polluted with respect to Ni. The CFs ranged from 0.43 to 1.36 (average of 0.87 ) for As, 0.12 to 0.41 (average of 0.26) for $\mathrm{Cr}, 0.28$ to 1.05 (average of 0.62 ) for $\mathrm{Cu}, 0.41$ to 1.32 (average of 0.86 ) for $\mathrm{Ni}, 0.16$ to 0.82 (average of 0.48 ) for $\mathrm{Pb}$, and 0.34 to 1.27 (average of 0.86 ) for $\mathrm{Zn}$. Moreover, the enrichments decreased according to the following order: $\mathrm{As}>\mathrm{Ni}>\mathrm{Zn}>\mathrm{Pb}>\mathrm{Cu}>\mathrm{Cr}$. The PLI values were between 0.26 and 0.84 , with a mean of 0.64 (Table 8). In general, the PLI results strongly suggest that the DKHNR has not been polluted by anthropogenic activities. Bai et al. (2011b) surveyed heavy metal contamination in wetland soils near tidal ditches and their primary sources. The contamination index and integrated contamination index show that the mean concentrations of these heavy metals were below the Class I criterion. Bai et al. (2012) investigated the characteristics of heavy metal pollution in tidal wetlands before and after the regulation regime. The sediment quality guidelines and geoaccumulation indices showed moderately or strongly polluted As and Cd levels and unpolluted or moderately polluted $\mathrm{Cu}, \mathrm{Pb}$, and $\mathrm{Zn}$ levels. Due to the demands that are imposed by the economic growth of the country, greater attention must be given to heavy metal contamination because areas of ecological relevance are now positioned to become disposal sites for large volumes of dredged material, putting large coastal ecosystems at risk.

Comparisons of the heavy metal concentration in DKHNR with other coastal areas

Some specific agencies have developed enforcements and criteria to characterize and classify contaminated soils. The Environmental Quality Standard for Soil (GB 15618-1995) have been utilized as an informal tool to identify relevant contaminants and to evaluate potential ecological heavy metal toxicity in relation to possible adverse effects (Choueri et al. 2009). Class I is a suitable criterion for maintaining natural background

Table 8 The PLI value in the DKHNR of the three layers

\begin{tabular}{llll}
\hline & The first layer & The second layer & The third layer \\
\hline $\mathrm{As}$ & 0.84 & 0.82 & 0.72 \\
$\mathrm{Cr}$ & 0.26 & 0.28 & 0.25 \\
$\mathrm{Cu}$ & 0.59 & 0.65 & 0.54 \\
$\mathrm{Ni}$ & 0.84 & 1.00 & 0.85 \\
$\mathrm{~Pb}$ & 0.46 & 0.44 & 0.36 \\
$\mathrm{Zn}$ & 0.84 & 0.82 & 0.72 \\
\hline
\end{tabular}


levels and protecting marine life habitats, including fishing and nature uses and rare and endangered species; Class II and Class III are applied for regulating general industrial use and coastal tourism (Li et al. 2013). None of the soil samples were considered to be polluted with heavy metals because their concentrations were all within the levels of Class I. Therefore, DKHNR were clean enough to be classified as Class I in terms of heavy metal concentrations. The comparison of mean soil heavy metal concentration in China and the main river estuary demonstrates that the concentrations of $\mathrm{Cu}, \mathrm{Pb}$, $\mathrm{Zn}, \mathrm{Cd}, \mathrm{Cr}$, As, and Ni were lower than in Baiyangdian Lake (Gao et al. 2013), Baohai Bay (Hu et al. 2013b), southern Bohai Bay (Hu et al. 2013a), and coastal Shandong Peninsula (Li et al. 2013) (Table 9). A reason is that Baiyangdian Lake receives nutrient inputs from domestic and industrial sewage and aquaculture wastewater (Gao et al. 2013). The concentration of heavy metals is close to the Changhua River estuary and Dongzhai Habor of Hainan Island (Hu et al. 2013a, b). The source of $\mathrm{Cd}, \mathrm{Cr}, \mathrm{Cu}, \mathrm{Hg}, \mathrm{Ni}$, and $\mathrm{Zn}$ in Hainan Island resulted primarily from natural weathering processes, whereas $\mathrm{As}$ and $\mathrm{Pb}$ were mainly attributed to anthropogenic sources. The metal levels in Hainan were at low-to-median levels, which is consistent with the fact that Hainan Island is still in low exploitation, and its mangroves suffer little impact from human activities (Qiu et al. 2011). Moreover, the concentration is much lower than in the Pear River Estuary because the Pearl River Estuary is a typical region of a fragile coastal ecosystem that has excessive anthropogenic activities, especially coastal reclamation, rapid economic growth, and urban development (Bai et al. 2011d). Element background data of Shandong Province from China National Environmental Monitoring Center (CNEMC) are chosen as environmental background concentration to evaluate the degree of anthropogenic metal contamination. The rocks representing environmental background are hardly got in the study area. The old structures are completely changed owing to intensive human activities. These are the reasons that the background values are not collected under rocks or under old structures to reduce issues with contamination. Moreover, the Shandong Province has plenty of mineral resource and has caused the high level of background value because the value is computed using the overall soil points in Shandong Province. The study area is located in the Yellow River Delta and has relative good in vegetation and the low level of industrial development level in
YRD. However, the concentration is much lower than Bai's result in that the mean concentrations of these heavy metals, except for As and Cd, were lower than the Class I criteria (Bai et al. 2011b). Due to the effects of tidal seawater, Suaeda salsa is the dominant plant species in the tidal wetlands along the tidal ditch. Moreover, the concentration of heavy metal is also lower than in Gironde Estuary, France, Mekong River, Sunderban wetland in India, and Newington in Australia (Table 9).

Numerical Soils Quality Guidelines (SQGs) have been used in North America for both freshwater and marine ecosystem and have been used to identify contaminants that are of concern in aquatic ecosystems (MacDonald et al. 2000; Hu et al. 2013a, b). SQGs were applied to this study for the assessment of the ecotoxicological sense of trace element concentrations with the threshold effect level (TEL) and probable effect level (PEL) values (Long et al. 2000). The TELs were intended to present chemical concentrations below which adverse biological effects rarely occur, and the PELs were intended to present the lower limit of the range of chemical concentrations above which adverse biological effects frequently occur (Gao et al. 2013). The SQGs guidelines indicated that all of the soil samples except for As and Ni did not exceed the TEL. However, the element As was present at 27 sites between the TEL and PEL values, which implies that occasional biological effects could occur. These findings demonstrated that an adverse toxic impact to the estuary ecosystem might not be expected. However, almost all of the samples did not exceed the PEL values, and thus, toxic effects of long-term exposure to the contaminants can be expected.

Environmental implication of heavy metal pollution

The soil environmental quality in China is affected by many accumulated influences from multiple factors, and soil pollution is accumulated for a long period during an economic and social development process. Human disturbances provide a major stress on almost all ecosystems (Chandra et al. 2013). Coastal and estuarine ecosystems are now facing increasing metal pollution stress (Pan and Wang 2012). The characteristics of coastal ecosystems that are subjected to intensive anthropogenic activities make them susceptible to heavy metal pollution. Measures should be taken immediately to reduce metal discharge from various anthropogenic sources 
Table 9 Mean soil heavy metal concentrations and As concentrations in major worldwide river deltas and the quality guidelines in various countries $\left(\mathrm{mg} \mathrm{kg}^{-1}\right)$

\begin{tabular}{|c|c|c|c|c|c|c|c|c|}
\hline Location & $\mathrm{Cu}$ & $\mathrm{Pb}$ & $\mathrm{Zn}$ & $\mathrm{Cd}$ & $\mathrm{Cr}$ & As & $\mathrm{Ni}$ & Reference \\
\hline \multirow[t]{2}{*}{ Yellow River Estuary, Shandong } & 31.39 & 29.24 & 95.79 & 0.88 & 64.06 & 31.66 & 28.12 & Bai et al. (2011c) \\
\hline & 31.94 & 28.99 & 91.33 & 0.96 & & 40.75 & & Bai et al. (2012) \\
\hline Diaokouhe Natural Reserve, YRD, China & 14.77 & 12.47 & 54.82 & 0.034 & 17.41 & 8.09 & 22.28 & This study \\
\hline Bohai Bay & 22.7 & 21.7 & 71.7 & & 33.5 & & 30.5 & Hu et al. (2013b) \\
\hline Southern Bohai Bay & 22.7 & 21.7 & 71.7 & 0.14 & 33.5 & & 30.5 & Hu et al. (2013a) \\
\hline Coastal Shanong Peninsula (Yellow Sea) & 20 & 28.4 & 74.7 & & 57.8 & & 31.2 & Li et al. (2013) \\
\hline Yangtze River Estuary & 32.13 & 27.82 & 98.44 & 0.28 & 78.9 & & 31.8 & Zhang et al. (2009a, b) \\
\hline \multirow[t]{2}{*}{ Pearl River Estuary, Reclaimed wetland } & 51.52 & 32.23 & 127.41 & 1.18 & 104.68 & & 48.14 & Bai et al. (2011d). \\
\hline & 68.2 & 32.3 & 311.1 & 4.22 & & & & Li et al. (2007) \\
\hline Pearl River Estuary & 63.9 & 68.3 & 172.0 & & 80.7 & & 46.6 & Yang et al. (2012) \\
\hline College Town, Guangzhou & 42.4 & 73.7 & 166.9 & 1.1 & 95.4 & & 40.8 & Xiao et al. (2012) \\
\hline Baiyangdian Lake, North China & 43.02 & 30.72 & 128.76 & 0.67 & 81.33 & 38.37 & 43.85 & Gao et al. (2013) \\
\hline Changhua River Estuary, Hainan Island & 15.0 & 27.0 & 73.7 & 0.09 & 53.1 & 9.5 & 23.0 & Hu et al. (2013a) \\
\hline Dongzhai Habor, Hainan Island & 18 & 19 & 57 & 0.11 & 40 & 13 & & Qiu et al. (2011) \\
\hline Gironde Estuary, France & 24.5 & 46.8 & 106 & 0.48 & 78.4 & 18.7 & 31.7 & Larrose et al. (2010) \\
\hline Mekong River & 53 & 35 & 138 & 0.5 & & & & \\
\hline Newington, Australia & 71.3 & 121.9 & 229.0 & & & & & MacFarlane et al. (2003) \\
\hline Sunderban wetland, India & 41.2 & 18.0 & 72.4 & 0.149 & 94.2 & 22.5 & 42.9 & Chatterjee et al. (2009). \\
\hline Class $\mathrm{I}^{\mathrm{a}}$ & 35 & 35 & 100 & 0.2 & 90 & 15 & 40 & SEPAC (1995) \\
\hline Class II ${ }^{\mathrm{a}}$ & 100 & 300 & 250 & 0.3 & 300 & 25 & 50 & \\
\hline Class III ${ }^{\mathrm{a}}$ & 400 & 500 & 500 & 1.0 & 400 & 30 & 200 & \\
\hline TEL & 35.7 & 35 & 123 & 0.596 & 37.3 & 5.9 & 18 & $\begin{array}{l}\text { Long et al. (1995); } \\
\text { MacDonald et al. (2000) }\end{array}$ \\
\hline PEL & 197 & 91.3 & 315 & 3.53 & 90 & 17 & 36 & \\
\hline Average upper crust of East China & 28 & 17 & 67 & 0.09 & 92 & 5.0 & 47 & $\begin{array}{l}\text { Rudnick and Gao (2003); } \\
\text { Gao et al. (1998) }\end{array}$ \\
\hline Background values $^{\mathrm{b}}$ & 24 & 25.8 & 63.5 & 0.084 & 66 & 9.3 & 25.8 & CNEMC (1990) \\
\hline
\end{tabular}

TEL threshold effect level, PEL probable effect level (MacDonald et al. 2000)

${ }^{\text {a }}$ Environmental Quality Standard for Soil (GB 15618-1995)

${ }^{\mathrm{b}}$ Background value of Shandong Province (China National Environmental Monitoring Center 1990)

because continued rapid economic growth is expected in China. The State Council upgraded the "Shandong Peninsula Blue Economic Zone Development Plan" into a national strategy in January 2011. Therefore, the management of heavy metal contamination is critically required.

The central government should implement a soil restoration project and conduct soil pollution treatment demonstration pilot work at typical sites and establish soil pollution treatment technology systems step by step and control the misuse of agricultural input material during agricultural production. Environmental legislation that is related to the prevention of pollution in the DKHNR is based on a range of national laws and regulations. Policies that heavily emphasize economic development should be amended because environmentally friendly and sustainable long-term growth is needed. Implementing and enforcing stricter environmental regulations can decrease heavy metal pollution (Hosono et al. 2011). Investigating heavy metal pathways, 
mechanisms, and the response of marine organisms to heavy metal contamination is fundamental to the implementation of preventative and remediative strategies. Hydrological processes play an important role in metal transportation and deposition and in typical anthropogenic disturbances (Caeiro et al. 2005; Pan and Wang 2012). Environmental impact assessment (EIA) can contribute to heavy metal management by reducing heavy metal pollutants that are generated by industrial processes. EIA should also allow for the best dredging and reclamation activity practices, to reduce the risk of mobilizing the contaminants due to sediment disturbances (Naser 2013). Land-use and land-cover change (LUCC) analysis have been proven to be an effective way of determining the effects of human disturbances. Long-term monitoring and assessment of pollution levels both before and after the water transfer in the Diaokouhe River should be conducted to provide technical decision-making support and to optimize ecological water transfer plans. Therefore, further cooperation between local and regional institutions and organizations that are concerned with scientific research and the monitoring of heavy metal concentrations, such as hydrological processes and LUCC analysis, is needed.

\section{Conclusions}

Due to rapid economic and industrial developments, anthropogenic pollutants have increased substantially, resulting in heavy metal contamination in coastal areas in recent decades (Pan and Wang 2012). In the available literature, Bai et al. (2012) applied a geoaccumulation index, correlation analysis, factor analysis, and sediment quality guidelines to compare soil heavy metal concentrations before and after flow-sediment regulation in the tidal freshwater and salt marshes of the Yellow River Delta. The results showed that the concentrations of the heavy metals $\mathrm{As}$ and $\mathrm{Cd}$ in the marsh soils are much higher after flow-sediment regulation than before (Bai et al. 2012). Cui et al. (2011) analyzed nine heavy metals in different media and aquatic organisms in newly formed wetlands of the YRD. Bai et al. (2011b) used the contamination index and integrated contamination index to explore the wetland soils' heavy metal concentration along the tidal ditch and found that it was contaminated at a low level by $\mathrm{As}$ and $\mathrm{Cd}$ and found no contamination levels for $\mathrm{Cr}, \mathrm{Cu}, \mathrm{Ni}, \mathrm{Pb}$, and $\mathrm{Zn}$. $\mathrm{Li}$ et al. (2013) applied a geoaccumulation index, enrichment factor, contamination factor, and PLI to evaluate the degree of anthropogenic metal contamination. Nie et al. (2010) analyzed the effects of petroleum-hydrocarbon spillage on the concentrations and distributions of heavy metals. Sun et al. (2013) explored the P cycling in the two $S$. salsa marshes and the low S. salsa marsh of the Yellow River estuary. Moreover, Huang applied the HJ-1 remote sensing data to monitor wetland restoration in the abandoned Yellow River Delta. From the above analysis, we can see that there is little literature to explore the soil heavy metal properties especially since the wetland restoration policy was implemented. The study sampled soil profiles to monitor the heavy metal status using statistical analysis, such as cluster analysis, geoaccumulation index, and pollution load index, to identify potential natural and anthropogenic sources. The surficial and vertical distributions of trace metals in the soil profiles of different land-use types in the DKHNR were examined. In general, the heavy metal concentrations decreased with depth, which indicates recent heavy metal pollution. Strengthened hydrodynamic conditions and a change in soil properties could be the major causes for redistribution, deposition, and accumulation of heavy metals. The correlation analysis results demonstrated a significant and positive correlation $(P<0.01)$ between $\mathrm{Cr}$ and $\mathrm{Ni}, \mathrm{Cr}$ and $\mathrm{Pb}, \mathrm{Cu}$ and $\mathrm{Pb}, \mathrm{Ni}$ and $\mathrm{Pb}$, and $\mathrm{Pb}$ and $\mathrm{Zn}$ due to anthropogenic activities, whereas no other significant correlations were found among the other metals. Moreover, the concentrations were well below the Class I criteria for all metals, which indicates that adverse effects on aquatic biota should rarely occur. Moreover, $\mathrm{As}, \mathrm{Cr}, \mathrm{Cu}, \mathrm{Ni}, \mathrm{Pb}$, and $\mathrm{Zn}$ had lower geoaccumulation index values, averaging less than 0 in the three soil layers, which indicated that the soils have remained unpolluted with respect to $\mathrm{Cu}, \mathrm{Pb}$, and $\mathrm{Zn}$. The contamination factor $(\mathrm{CF})$ also revealed that the region has appeared to have relatively low contamination levels. The PLI results strongly suggested that the study area has not been polluted by anthropogenic activities. Furthermore, the CF and $I_{\text {geo }}$ also clearly indicate that the coastal ecosystems remain in their pristine state with respect to metal pollution (Wang et al. 2013). The results obtained deepen our understanding and expand our information about soil heavy metal vertical changes in coastal and estuarine deltas and could provide useful comments for land use management and soil remediation in environmental protection. We have little knowledge of the heavy metal concentrations in the 
abandoned Yellow River Delta in recent years, and it has been thought that contamination of heavy metals in the abandoned Yellow River Delta should be relatively large owing to the deterioration of the river estuary. Cui et al. (2011) found that the concentrations of heavy metals in the newly formed wetlands are lower than those in other similar regions due to having fewer exposures to contamination. To our surprise, the soil heavy metal concentration in the DKHNR is lower than in other major estuarine wetlands. However, an increase in the heavy metal concentrations was monitored by comparing the concentrations that were obtained during the study with those data that were obtained during the 1990s.

A better understanding of the current heavy metal pollution status in coastal ecosystems is important for the sustainable development of marine ecosystems. Additional studies are required to confirm changes in the heavy metal characteristics and their accumulation processes before and after restoration projects. The national "Shandong peninsula Blue Economic Zone Development Plan" compels further understanding of the distributions and potential risks of metal pollution along the eastern coast of China, where rapid economic and urban development has occurred and metal pollution has become a noticeable problem. The regions continue to face the impact of increased anthropogenic activities, and these areas should be listed as important ecological system protection zones for the reserved Yellow River flow path; large-scale industrial development should be prohibited. Therefore, more stringent environmental protection measures are required to control and monitor heavy metal concentrations and distributions due to the discharge of heavy metals from anthropogenic sources.

Acknowledgments This research is supported by the National Natural Science Foundation of China (No. 41101084, 41361018, 41371104), National Basic Research Program of China (2010CB950900; 2009CB421100), and the open fund of Jiangsu key laboratory of environmental change \& ecological construction. We would like to express our gratitude to two anonymous reviewers for their useful comments for previous version.

\section{References}

Arik, F., \& Yaldiz, T. (2010). Heavy metals determination and pollution of the soil and plants of southeast Tavsanli (Kütabya, Turkey). Clean-Soil. Air. Water, 38, 1017-1030.
Bai, J. H., Wang, Q. G., Zhang, K. J., Cui, B. S., Liu, X. H., Huang, L. B., Xiao, R., \& Gao, H. F. (2011a). Trace element contaminations of roadside soils from two cultivated wetlands after abandonment in a typical plateau lakeshore, China. Stochastic Environmental Research and Risk Assessment, 25(1), 91-97.

Bai, J. H., Huang, L. B., Yan, D. H., Wang, Q. G., Gao, H. F., Xiao, R., \& Huang, C. (2011b). Contamination characteristics of heavy metals in wetland soils along a tidal ditch of the Yellow River Estuary, China. Stochastic Environmental Research and Risk Assessment, 25, 671-676.

Bai, J. H., Cui, B. S., Chen, B., Zhang, K. J., Deng, W., Gao, H. F., \& Xiao, R. (2011c). Spatial distribution and ecological risk assessment of heavy metals in surface sediments from a typical plateau lake wetland, China. Ecological Modelling, 222, 301-306.

Bai, J. H., Xiao, R., Cui, B. S., Zhang, K. J., Wang, Q. G., Liu, X. H., Gao, H. F., \& Huang, L. B. (2011d). Assessment of heavy metal pollution in wetland soil from the young and old reclaimed regions in the Pearl River Estuary, South China. Environmental Pollution, 159, 817-824.

Bai, J. H., Xiao, R., Zhang, K. J., \& Gao, H. F. (2012). Arsenic and heavy metal pollution in wetland soils from tidal freshwater and salt marshes before and after the flow-sediment regulation regime in the Yellow River Delta, China. Journal of Hydrology, 450, 244-253.

Barba-Brioso, C., Fernández-Caliani, J. C., Miras, A., Cornejo, J., \& Galán, E. (2010). Multi-source water pollution in a highly anthropized wetland system associated with the estuary of Huelva (SW Spain). Marine Pollution Bulletin, 60, 1259-1269.

Bastami, K. D., Bagheri, H., Haghparst, S., Soltani, F., Hamzehpoor, A., \& Bastami, M. D. (2012). Geochemical and geo-statistical assessment of selected heavy metals in the surface sediments of the Gorgan Bay, Iran. Marine Pollution Bulletin, 64, 2877-2884.

Caeiro, S., Costa, M. H., Ramos, T. B., Fernandes, F., Silveira, N., Coimbra, A., Medeiros, G., \& Painho, M. (2005). Assessing heavy metal contamination in Sado Estuary sediment: an index analysis approach. Ecological Indicator, 5, 151-169.

Canuto, E. A. B., Garcia, C. A. B., Alves, J. P. H., \& Passos, E. A. (2013). Mobility and ecological risk assessment of trace metals in polluted estuarine sediments using a sequential extraction scheme. Environmental Monitoring and Assessment, 185, 6173-6185.

Chandra, A. S., Rath, P., Chandra, P. U., Kumar, P. P., \& Bramha, S. (2013). Application of sequential leaching, risk indices and multivariate statistics to evaluate heavy metal contamination of estuarine sediments: Dhamara Estuary, East Coast of India. Environmental Monitoring and Assessment, 185, 6719-6737.

Chatterjee, M., Massolo, S., Sarkar, S. K., Bhattacharya, A. K., Bhattacharya, B., Satpathy, K. K., \& Saha, S. (2009). An assessment of trace element contamination in intertidal sediment cores of Sunderban mangrove wetland, India for evaluating sediment quality guidelines. Environmental Monitoring and Assessment, 150, 307-322.

China National Environmental Monitoring Center (CNEMC). (1990). Chinese elemental background values for soils. Beijing: Chinese Environmental Science Press.

Choueri, R. B., Cesar, A., Abessa, D. M. S., Torres, R. J., Morais, R. D., Riba, I., Pereira, C. D. S., Nascimento, M., Mozeto, A. A., \& DelValls, A. T. (2009). Development of site-specific 
sediment quality guidelines for North and South Atlantic littoral zones: comparison against national and international sediment quality benchmarks. Journal of Hazardous Materials, 170, 320-331.

Cui, B. S., Yang, Q. C., Yang, Z. F., \& Zhang, K. J. (2009). Evaluating the ecological performance of wetland restoration in the Yellow River Delta, China. Ecological Engineering, 35, 1090-1103.

Cui, B. S., Zhang, Q. J., Zhang, K. J., Liu, X. H., \& Zhang, H. G. (2011). Analyzing trophic transfer of heavy metals for food webs in the newly-formed wetlands of the Yellow River Delta, China. Environmental Pollution, 159, 1297-1306.

Cui, L. J., Gao, C. J., Zhao, X. S., Ma, Q. F., Zhang, M. Y., Li, W., Song, H. T., Wang, Y. F., Li, S. N., \& Zhang, Y. (2013). Dynamics of the lakes in the middle and lower reaches of the Yangtze River basin, China, since late nineteenth century. Environmental Monitoring and Assessment, 185, 4005-4018.

Deng, B., Zhang, J., Zhang, G. R., \& Zhou, J. Z. (2010). Enhanced anthropogenic heavy metal dispersal from tidal disturbance in the Jiaozhou Bay, North China. Environmental Monitoring and Assessment, 161, 349-358.

Dou, Y. G., Li, J., Zhao, J. T., Hua, B. Q., \& Yang, S. Y. (2013). Distribution, enrichment and source of heavy metals in surface sediments of the eastern Beibu Bay, South China Sea. Marine Pollution Bulletin, 67, 137-145.

Fang, T. H., Li, J. Y., Feng, H. M., \& Chen, H. Y. (2009). Distribution and contamination of trace metals in surface sediments of the East China Sea. Marine Environmental Research, 68, 178-187.

Feng, H., Jiang, H. Y., Gao, W. S., Weinstein, M. P., Zhang, Q. F., Zhang, W. G., Yu, L. Z., Yuan, D. K., \& Tao, J. H. (2011). Metal contamination in sediments of the western Bohai Bay and adjacent estuaries, China. Journal of Environmental Management, 92, 1185-1197.

Gan, H. Y., Lin, J. Q., Liang, K., \& Xia, Z. (2013). Selected trace metals $(\mathrm{As}, \mathrm{Cd}$, and $\mathrm{Hg}$ ) distribution and contamination in the coastal wetland sediment of the northern Beibu Gulf, South China. Marine Pollution Bulletin, 66, 252-258.

Gao, S., Luo, T. C., Zhang, B. R., Zhang, H. F., Han, Y. W., Zhao, Z. D., \& Hu, Y. K. (1998). Chemical composition of the continental crust as revealed by studies in East China. Geochimica et Cosmochimica Acta, 62, 1959-1975.

Gao, H. F., Bai, J. H., Xiao, R., Liu, P. P., Jiang, W., \& Wang, J. J. (2013). Levels, sources and risk assessment of trace elements in wetland soils of a typical shallow freshwater lake, China. Stochastic Environmental Research and Risk Assessment, 27, 275-284.

Ghrefat, H. A., Abu-Rukah, Y., \& Rosen, M. A. (2011). Application of geoaccumulation index and enrichment factor for assessing metal contamination in the sediments of Kafrain Dam, Jordan. Environmental Monitoring and Assessment, 178, 95-109.

Han, Y. M., Du, P. X., Cao, J. J., \& Posmentier, E. S. (2006). Multivariate analysis of heavy metal contamination in urban dusts of Xi' an, Central China. Science of Total Environment, $355,176-186$.

Hosono, T., Su, C., Delinom, R., Umezawa, Y., Toyata, T., Kaneko, S., \& Taniguchi, M. (2011). Decline in heavy metal contamination in marine sediments in Jakarta Bay, Indonesia due to increasing environmental regulations. Estuarine Coastal Shelf Science, 92, 297-306.
Hu, B. Q., Li, J., Zhao, J. T., Yang, J., Bai, F. L., \& Dou, Y. G. (2013a). Heavy metal in surface sediments of the Liaodong Bay, Bohai Sea; distribution, contamination and sources. Environmental Monitoring and Assessment, 185, 5071-5083.

Hu, B. Q., Li, G. G., Li, J., Bi, J. Q., Zhao, J. T., \& Bu, R. Y. (2013b). Spatial distribution and ecotoxicological risk assessment of heavy metals in surface sediments of the southern Bohai Bay, China. Environment Science and Pollution Research, 20, 4099-4110.

Huang, C., Liu, G. H., Fu, X., Li, Y. F., Liu, Q. S., \& Wang, X. G. (2012). Monitoring and evaluation of wetland restoration in the abandoned Diaokou Estuary of Yellow River Delta based on HJ-1 remote sensing data. Progress in Geography, 31(5), 570-576 (in Chinese).

Ip, C. C. M., Li, X., Zhang, G., Wai, O. W. H., \& Li, Y. (2007). Trace metal distribution in sediments of the Pearl River Estuary and the surrounding coastal sea, South China. Environmental Pollution, 147, 311-323.

Jiao, W., Ouyang, W., Hao, F. H., Wang, F. L., \& Liu, B. (2014). Long-term cultivation impact on the heavy metal behavior in a reclaimed wetland, Northeast China. Journal of Soils Sediments, 14, 567-576.

Karim, Z., Qureshi, B. A., Mumtaz, M., \& Qureshi, S. (2013). Heavy metal content in urban soils as an indicator of anthropogenic and natural influences on landscape of Karachi-A multivariate spatio-temporal analysis. Ecological Indicator. doi:10.1016/j.ecolind.2013.07.020.

Larrose, A., Coynel, A., Schäfer, J., Blanc, G., Massé, L., \& Maneux, E. (2010). Assessing the current state of the Gironde Estuary by mapping priority contaminant distribution and risk potential in surface sediment. Applied Geochemistry, 25, 1912-1923.

Li, Q. S., Wu, Z. F., Chu, B., Zhang, N., Cai, S. S., \& Fang, J. H. (2007). Heavy metals in coastal wetland sediments of the Pearl River Estuary, China. Environmental Pollution, 149, 158-164.

Li, J. L., He, M., Han, W., \& Gu, Y. F. (2009). Analysis and assessment on heavy metal sources in the coastal soils developed from alluvial deposits using multivariate statistical methods. Journal of Hazardous Material, 164, 976-981.

Li, G. G., Hu, B. Q., Bi, J. Q., Leng, Q. A., Xiao, C. Q., \& Yang, Z. C. (2013). Heavy metals distribution and contamination in surface sediments of the coastal Shandong Peninsula (Yellow Sea). Marine Pollution Bulletin, 76, 420-426.

Lin, C. E., Chen, C. T., Kao, C. M., Hong, A., \& Wu, C. Y. (2011). Development of the sediment and water quality management strategies for the Salt-water River, Taiwan. Marine Pollution Bulletin, 63, 528-534.

Liu, E. F., Shen, J., Yang, L. Y., Zhang, E. L., Meng, X. H., \& Wang, J. J. (2010). Assessment of heavy metal contamination in the sediments of Nansihu Lake Catchment, China. Environmental Monitoring and Assessment, 161, 217-227.

Liu, J. L., Wu, H., Feng, J. X., Li, Z. J., \& Lin, G. H. (2014). Heavy metals contamination and ecological risk assessments in the sediments and zoobenthos of selected mangrove ecosystems, South China. Catena, 119, 136-142.

Long, E. R., MacDonald, D. D., Smith, S. L., \& Calder, F. D. (1995). Incidence of adverse biological effects within ranges of chemical concentrations in marine and estuarine sediments. Environmental Management, 19, 81-97.

Long, E. R., MacDonald, D. D., Severn, C. G., \& Hong, C. B. (2000). Classifying probabilities of acute toxicity in marine 
sediments with empirically derived sediment quality guidelines. Environmental Toxicology and Chemistry, 19, 2598-2601.

Lotze, H. K., Lenihan, H. S., Bourque, B. J., Bradbury, R. H., Cooke, R. G., Kay, M. C., Kidwell, S. M., Kirby, M. X., Peterson, C. H., \& Jackson, J. B. C. (2006). Depletion, degradation, and recovery potential of estuaries and coastal seas. Science, 312, 1806-1809.

MacDonald, D. D., Ingersoll, C. G., \& Berger, T. A. (2000). Development and evaluation of consensus-based sediment quality guidelines for freshwater ecosystems. Archives of Environmental Contamination and Toxicology, 39, 20-31.

MacFarlane, G. R., Pulkownik, A., \& Burchett, M. D. (2003). Accumulation and distribution of heavy metals in the grey mangrove, Avicennia marina (Forsk.) Vierh: biological indication potential. Environmental Pollution, 123, 139-151.

Macias, C. G., Schifter, I., Lluch-Cota, D. B., Mendez-Rodriguez, L., \& Vazquez, S. H. (2006). Distribution, enrichment and accumulation of heavy metals in coastal sediments of Salina Cruz Bay, Mexico. Environmental Monitoring and Assessment, 118, 211-230.

Magesh, N. S., Chandrasekar, N., Krishna, S. K., \& Glory, M. (2013). Trace element contamination in the estuarine sediments along Tuticorin coast-Gulf of Mannar, southeast coast of India. Marine Pollution Bulletin, 73, 355-361.

Müller, G. (1981). Die Schwermetallbelastung der Sedimente des Neckars und Seiner Nebenflusse: eine Bestandsaufnahme. Chem. Zeit., 105, 157-164.

Naser, H. A. (2013). Assessment and management of heavy metal pollution in the marine environment of the Arabian Gulf: a review. Marine Pollution Bulletin, 72, 6-13.

Nazeer, S., Hashmi, M. Z., \& Malik, R. N. (2014). Heavy metals distribution, risk assessment and water quality characterization by water quality index of the River Soan, Pakistan. Ecological Indicators, 43, 262-270.

Nie, M., Xian, N. X., Fu, X. H., Chen, X. F., \& Li, B. (2010). The interactive effects of petroleum-hydrocarbon spillage and plant rhizosphere on concentrations and distribution of heavy metals in sediments in the Yellow River Delta, China. Journal of Hazardous Materials, 174, 156-161.

Nobi, E. P., Dilipan, E., Thangaradjou, T., Sivakumar, K., \& Kannan, L. (2010). Geochemical and geo-statistical assessment of heavy metal concentration in the sediments of different coastal ecosystems of Andaman islands, India. Estuarine Coastal Shelf Science, 87, 253-264.

Pan, K., \& Wang, W. X. (2012). Trace metal contamination in estuarine and coastal environments in China. Science of Total Environment, 421, 3-16.

Panda, U. C., Rath, P., Bramha, S. N., \& Sahu, K. C. (2010). Application of factor analysis in geochemical speciation of heavy metals in the sediments of a lake system-Chilika (India): a case study. Journal of Coastal Research, 26(5), 860-868.

Pekey, H., Karaka, D., Ayberk, S., Tolun, L., \& Lu, M. B. (2004). Ecological risk assessment using trace elements from surface sediments of Izmit Bay (Northeastern Marimara Sea) Turkey. Marine Pollution Bulletin, 48, 946-953.

Qiu, Y. W., Yu, K. F., Zhang, G., \& Wang, W. X. (2011). Accumulation and partitioning of seven trace metals in mangroves and sediment cores from three estuarine wetlands of Hainan Island, China. Journal of Hazardous Materials, 190, 631-638.
Raj, S. M., \& Jayaprakash, M. (2008). Distribution and enrichment of trace metals in marine sediments of Bay of Bengal, off Ennore, south-east coast of India. Environmental Geology, 56, 207-217.

Ranjan, R. K., Singh, G., Routh, J., \& Ramanathan, A. L. (2013). Trace metal fractionation in the Pichavaram mangrove-estuarine sediments in southeast India after the tsunami of 2004. Environmental Monitoring and Assessment, 185, 8197-8213.

Rodrigues, S. K., Abessa, D. M. S., \& Machado, E. C. (2013). Geochemical and ecotoxicological assessment for estuarine surface sediments from Southern Brazil. Marine Environmental Research, 91, 68-79.

Rudnick, R. L., \& Gao, S. (2003). Composition of the continental crust. In D. H. Heinrich \& K. T. Karl (Eds.), Treatise on geochemistry (pp. 1-64). Pergamon: Oxford.

Sale, P., Feary, D., Burt, J., Bauman, A., Cavalcante, G., Drouillard, K., Kjerfve, B., Marquis, E., Trick, C., Usseglio, P., \& Van Lavieren, H. (2010). The growing need for sustainable ecological management of marine communities of the Persian Gulf. AMBIO, 40, 4-17.

State Environmental Protection Administration of China (SEPAC) (1995) Chinese Environmental Quality Standard for Soils (GB 15618-1995).

Singh, K. P., Malik, A., Mohan, D., \& Sinha, S. (2004). Multivariate statistical techniques for the evaluation of spatial and temporal variation in water quality of Gomati River (India) - a case study. Water Research, 38, 3980-3992.

Sun, Z. G., Mou, X. J., Tian, H. Q., Song, H. L., Jiang, H. H., Zhao, J. Y., Sun, W. L., \& Sun, W. G. (2013). Phosphorus biological cycle in the different Suaeda salsa marshes of the Yellow River estuary, China. Environment Earth Science, 69, 2595-2608.

Varol, M. (2011). Assessment of heavy metal contamination in sediments of the Tigris River (Turkey) using pollution indices and multivariate statistical techniques. Journal of Hazardous Material, 195, 355-364.

Wang, A. J., \& Chen, J. (2009). Spatial variations in depthdistribution of trace metals in coastal wetland sediments from Quanzhou Bay, Fujian Province, China. Chinese Geographical Science, 19(1), 62-68.

Wang, S. L., Xu, X. R., Sun, Y. X., Liu, J. L., \& Li, H. B. (2013). Heavy metal pollution in coastal areas of South China: a review. Marine Pollution Bulletin, 76, 7-15.

Wedepohl, K. H. (1995). The composition of the continental crust. Geochim Cosmocheim Acta, 59, 1217-1232.

Xiao, R., Bai, J. H., Wang, Q. G., Gao, H. F., Huang, L. B., \& Liu, X. H. (2011). Assessment of heavy metal contamination of wetland soils from a typical aquatic terrestrial ecotone in Haihe River Basin. North China. Clear-Soil. Air. Water, 39, 612-618.

Xiao, R., Bai, J. H., Gao, H. F., Wang, J. J., Huang, L. B., \& Liu, P. P. (2012). Distribution and contamination assessment of heavy metals in water and soils from the College Town in the Pearl River Delta. China. Clear-Soil. Air. Water, 40(10), $1167-1173$

Xin, K., Huang, X., Hu, J. L., Li, C., Yang, X. B., \& Arndt, S. K. (2014). Land use change impacts on heavy metal sedimentation in mangrove wetlands - a case study in Dongzhai Harbor of Hainan, China. Wetlands, 34, 1-8.

Yang, Y. H., Fang, J. Y., Guo, D. L., Ji, C. J., \& Ma, W. H. (2010). Vertical patterns of soil carbon, nitrogen and carbon: nitrogen 
stoichiometry in Tibetan grasslands. Biogeoscience Discussion, 7, 1-24.

Yang, Y. Q., Chen, F. R., Zhang, L., Liu, J. S., Wu, S. J., \& Kang, M. L. (2012). Comprehensive assessment of heavy metal contamination in sediment of the Pearl River Estuary and adjacent shelf. Marine Pollution Bulletin, 64, 1947-1955.

Ye, C., Li, S. Y., Zhang, Y. L., \& Zhang, Q. F. (2011). Assessing soil heavy metal pollution in the water-level-fluctuation zones of the Three Gorges Reservoir, China. Journal of Hazardous Material, 191, 366-372.

Zamani-Ahmadmahmoodi, R., Esmaili-Sari, A., Mohammadi, J., Riyahi, B. A., \& Savabieasfahani, M. (2013). Spatial distribution of cadmium and lead in the sediments of the western Anzali wetlands on the coast of the Caspian Sea (Iran). Marine Pollution Bulletin, 74, 464-470.
Zhang, W. G., Feng, H., Chang, J. N., Qu, J. G., Xie, H. X., \& Yu, L. Z. (2009a). Heavy metal contamination in surface sediments of Yangtze River intertidal zone: an assessment from different indexes. Environmental Pollution, 157, 1533-1543.

Zhang, Y., Guo, F., Meng, W., \& Wang, X. Q. (2009b). Water quality assessment and source identification of Daliao river basin using multivariate statistical methods. Environmental Monitoring and Assessment, 152, 105-121.

Zhang, R., Zhou, L., Zhang, F., Ding, Y. J., Gao, J. R., Chen, J., Yan, H. Q., \& Shao, W. (2013). Heavy metal pollution and assessment in the tidal flat sediments of Haizhou Bay, China. Marine Pollution Bulletin, 74, 403-412.

Zhang, N. N., Zang, S. Y., \& Sun, Q. Z. (2014). Health risk assessment of heavy metals in the water environment of Zhalong Wetland, China. Ecotoxicology, 23, 518-526. 